\title{
1 Ancestry-specific polygenic scores and SNP heritability of 2 25(OH)D in African- and European-ancestry populations
}

3

5

6

Hatchell, Kathryn E. ${ }^{1}$; Lu, Qionshi'; Hebbring, Scott J. ${ }^{3}$; Michos, Erin D. ${ }^{4}$; Wood, Alexis C. ${ }^{5}$; Engelman, Corinne D. ${ }^{1}$

${ }^{1}$ Department of Population Health Sciences, University of Wisconsin-Madison School of Medicine and Public Health, Madison, Wisconsin, 53706, USA

${ }^{2}$ Department of Biostatistics and Medical Informatics, University of Wisconsin-Madison School of

10 Medicine and Public Health, Madison, Wisconsin, 53706, USA

$11{ }^{3}$ Center for Human Genetics, Marshfield Clinic Research Institute, Marshfield, Wisconsin, 54449, USA

$12{ }^{4}$ Ciccarone Center for the Prevention of Cardiovascular Disease, Johns Hopkins University School of

14 'USDA/ARS Children's Nutrition Research Center, Baylor College of Medicine, Houston, Texas, 77030, 15 USA

Short title: Ancestry-specific 25(OH)D PGS and SNP heritability

Precis: Ancestry-specific polygenic risk scores for 25(OH)D capture more genetic variance than do previous GWAS findings and could be leveraged to inform personalized vitamin D supplementation

Word Count: 4,965

\section{Correspondence:}

25 Kathryn E Hatchell

26155 Gibbs Street \#436

27 Rockville, MD 20850

28 Email: khatchell@geisinger.edu

Disclosures: The authors have nothing to declare. 


\section{Abstract:}

42 Context. Vitamin D inadequacy, assessed by 25-hydroxyvitamin D [25(OH)D], affects around $50 \%$ of 43 adults in the United States and is associated with numerous adverse health outcomes. Blood $25(\mathrm{OH}) \mathrm{D}$

44 concentrations are influenced by genetic factors that may determine how much vitamin $D$ intake is 45 required to reach optimal 25(OH)D. Despite large genome-wide association studies (GWASs), only a 46 small portion of the genetic factors contributing to differences in 25(OH)D levels has been discovered.

47 Objective. Therefore, knowledge of a fuller set of genetic factors could be useful for risk prediction of $4825(\mathrm{OH}) \mathrm{D}$ inadequacy, personalized vitamin D supplementation, and prevention of morbidity and mortality 49 from deficient $25(\mathrm{OH}) \mathrm{D}$.

50 Design. Using PRSice and weights from published African- and European-ancestry GWAS summary 51 statistics, ancestry-specific polygenic scores (PGSs) were created to capture a more complete set of 52 genetic factors.

53 Patients or Other Participants. Participants (European ancestry $n=9,569$, African ancestry $n=2,761$ ) 54 came from three cohort studies.

55 Main Outcome Measure(s). Blood concentrations of 25(OH)D.

56 Results. The PGS for African ancestry was derived using all input SNPs (a p-value cut-off of 1.0) and 57 had an $R^{2}$ of $0.3 \%$; for European ancestry, the optimal PGS used a p-value cut-off of $3.5 \times 10^{-4}$ in the 58 target/tuning dataset and had an $\mathrm{R}^{2}$ of $1.0 \%$ in the validation cohort. Those with highest genetic risk had $5925(\mathrm{OH}) \mathrm{D}$ that was $2.8-3.0 \mathrm{ng} / \mathrm{ml}$ lower than those with lowest genetic risk $\left(\mathrm{p}=0.0463\right.$ to $\left.3.2 \times 10^{-13}\right)$,

60 requiring an additional 467 to $500 \mathrm{IU}$ of vitamin $\mathrm{D}$ intake to maintain equivalent $25(\mathrm{OH}) \mathrm{D}$.

61 Conclusions. PGSs are a powerful predictive tool that could be leveraged for personalized vitamin D 62 supplementation to prevent the negative downstream effects of $25(\mathrm{OH}) \mathrm{D}$ inadequacy.

66 Keywords: Genetics, ancestry, vitamin D, diet, polygenic risk score, heritability 


\section{Introduction}

68

Vitamin D inadequacy, using the Institute of Medicine definition of a 25-hydroxyvitamin D [25(OH)D] concentration less than $20 \mathrm{ng} / \mathrm{mL}$, affects almost $50 \%$ of adults in the United States, with higher prevalence in those with darker skin tones (1-3). Observational studies show associations between low vitamin $\mathrm{D}$ concentrations and numerous adverse health outcomes, including autoimmune diseases, migraines, hypertension, dyslipidemia, cardiovascular events, and cardiovascular mortality (1,3-9). These studies are supported by recent Mendelian randomization studies which provide evidence for a causal relationship between low vitamin D concentrations and increased risk of obesity, ovarian cancer, hypertension, lower cognitive function during aging, multiple sclerosis, and all cause and cancer mortality (10-16). Furthermore, some clinical trials have shown that vitamin $D$ and calcium supplementation are important in the prevention of fractures and cardiovascular risk factors, while vitamin D supplementation alone may lower risk of cancers, diabetes and depression and may reduce inflammation and improve lung function in patients with cystic fibrosis $(7,17-25)$. Recent results from the Vitamin $D$ and Omrega-3 Trial (VITAL) showed null associations between vitamin D supplementation and cancer or cardiovascular disease. However, study design limits the interpretability of these findings; for example individuals with adequate $25(\mathrm{OH}) \mathrm{D}$ concentrations were included, and outside use of vitamin $\mathrm{D}$ before and during the trial were not restricted (26). Avoiding vitamin D inadequacy is important, however, as $25(\mathrm{OH}) \mathrm{D}$ concentrations over $50 \mathrm{ng} / \mathrm{mL}$ have been associated with increased morbidity and mortality $(3,27)$.

Clinical trials of vitamin $D$ have shown that individual response to vitamin $D$ supplementation is highly variable $(28,29)$. 25(OH)D concentrations are influenced by genetic factors and genetic variants may determine how much vitamin $\mathrm{D}$ intake is required to reach an optimal $25(\mathrm{OH}) \mathrm{D}$ blood concentration (3033). Therefore, knowledge of the genetic determinants of $25(\mathrm{OH}) \mathrm{D}$ concentrations could be useful for prediction of risk for vitamin $\mathrm{D}$ inadequacy, personalized vitamin $\mathrm{D}$ supplementation, and subsequent prevention of vitamin $\mathrm{D}$ associated morbidity and mortality due to $25(\mathrm{OH}) \mathrm{D}$ deficiency.

Variation in or near twelve genes (A2BP1, AMDHD1, ANO6/ARID2, CYP2R1, CYP24A1, DAB1, DHCR7, GC, GPR114, HTR2A, KIF4B, and SEC23A) has been associated with serum 25(OH)D at genome-wide levels of significance through published genome-wide association studies (GWASs) in those of European or African ancestry (1,34-37). However, only single nucleotide polymorphisms (SNPs) 
96 in or near four of these genes have been replicated (CYP2R1, CYP24A1, DHCR7, and GC), and together

97 account for a small portion of the variation in $25(\mathrm{OH}) \mathrm{D}$ concentrations, about $2.8 \%$ compared to the

98 estimated $20-40 \%$ heritability $(1,31,36)$. Such "missing heritability" is common in complex traits, and

99 could, in part, be attributed to many SNPs with small effects that do not reach a stringent genome-wide

100 significance threshold (38). A polygenic score (PGS), by comprising the weighted sum of trait-associated

101 alleles, may capture more trait variation than individual SNPs alone. PGSs have been shown to be more

102 powerful than individual SNP-based testing, are used in a wide variety of statistical techniques (e.g.,

103 Mendelian randomization), and have shown clinical promise, predicting Alzheimer's disease incidence

104 before the onset of symptoms that would result in a clinical diagnosis, and for dosing of antifibrinolytic

105 drugs based on activated partial thromboplastin time (aPTT) risk scores (39-42).

106

Yet challenges remain with developing PGS. Analyses suggest that only including SNPs reaching

107 genome-wide significance in a PGS fails to capture much of the heritable variation and reduces the

108 PGS's prediction accuracy. However, deciding on a p-value threshold for including SNPs a priori is

109 challenging. Recently, software has been developed which addresses this challenge, using summary

110 statistics from GWAS to calculate a number of PGSs across a wide range of $p$-value thresholds for SNP

111 inclusion and model fit statistics to determine the optimal threshold for predicting traits in a testing

112 dataset, which is often less stringent than the genome-wide level (43).

113 To date, only a handful of studies have calculated PGSs for vitamin D concentrations, generally

114 using only SNPs in genes that reached the stringent $p$-value threshold in existing vitamin D GWASs,

115 therefore missing much of the genetic contribution to the phenotype (32,44-47). Given that several

116 studies have reported genetic dependent response to vitamin D supplementation, PGSs hold predictive

117 and preventive promise in relation to vitamin $D$ concentrations $(30,48,49)$.

118 The goal of the current study was to calculate ancestry-specific PGSs for 25(OH)D in individuals

119 of European or African ancestry based on the results from a recent multi-ethnic GWAS meta-analysis

120 (37), and to validate the PGS performance in an independent sample. Additionally, the proportion of SNP

121 heritability captured by the PGS was quantified, using GCTA, and compared to that captured by the

122 genome-wide significant SNPs. 


\section{Materials and Methods}

125

126

127

128

129

130

131

132

\section{GWAS summary statistics}

The $\underline{\text { TRANS}}$-ethni $\underline{\underline{E}}$ Evaluation of vitamiN $\underline{\mathrm{D}}$ GWAS consortium (TRANSCEN-D), performed the largest multi-ethnic vitamin D GWAS meta-analysis to date and included 13 cohorts (9 of African ancestry, 3 of Hispanic ancestry and the SUNLIGHT discovery cohort, a consortium of 15 European cohorts) (37). Here, ancestry-specific summary statistics from the African- and European-ancestry cohorts of TRANSCEN-D were leveraged for weighting of each SNP included in the PGS (37). This is referred to as the base dataset.

\section{Target/tuning dataset for calculation of PGS}

Using weights from the base dataset, PGSs were developed in an ancestry-specific manner for subsets of European- and African-ancestry samples from the Atherosclerosis in Communities (ARIC) study, which contains European- and African- ancestry participants (50). These ARIC subsets are referred to as the target/tuning datasets. ARIC data were obtained through dbGaP Study Accession: phs000090.v4.p1. ARIC data were selected as the target/tuning dataset as they included both sexes and had dense genotyping, essential for development of a comprehensive and generalizable PGS. ARIC is a prospective epidemiologic study conducted across four United States sites: Wake Forest Baptist Medical Center, Winston-Salem, NC; University of Mississippi Medical Center, Jackson, MS; University of Minnesota, Minneapolis, MN; Johns Hopkins University, Baltimore, MD. ARIC includes 15,792 participants aged 45-64 at baseline, of which 9,086 have data required for this analysis (genomic data, $25(\mathrm{OH}) \mathrm{D}$, age, sex, body mass index (BMI), location and month of blood draw) which were ascertained at ARIC visit 2 (1990-1992). Of these 9,086 participants, 7,178 are of European ancestry. A random sample of 1,000 participants were chosen from the 7,178 eligible European-ancestry participants for tuning the optimal PGS model, the remaining samples were used to validate the PGS. From the 1,908 eligible participants of African ancestry from ARIC, only data from 57 participants had not been included in the TRANSCEN-D meta-analysis; these were used as the base dataset. Therefore, to ensure independence 
153 between the base and target/tuning datasets only these 57 African-ancestry participants were selected

154 into the target/tuning dataset.

PGS validation cohort

PGS validation was done using data combined across participants from three multi-ethnic

159 cohorts: ARIC, the Multi-ethnic Study of Atherosclerosis (MESA) and the Women's Health Initiative (WHI),

160 analyzed in an ancestry-specific manner. As above, ARIC provided data on 6,178 participants of

161 European ancestry for the validation cohort. MESA is a prospective study of men and women ages 45-84

162 who were recruited by Columbia University, New York, NY; Johns Hopkins University, Baltimore, MD;

163 Northwestern University, Chicago, IL; University of Minnesota, Minneapolis, MN; University of California

164 at Los Angeles, Los Angeles, CA and Wake Forest University, Winston-Salem, NC. Serum 25(OH)D was

165 measured at MESA exam 1 (July 2000-August 2002). MESA data were obtained through dbGaP Study

166 Accession: phs000209.v13.p3. MESA provided data on 1,936 European- and 342 African-ancestry

167 participants who maintained independence from TRANSCEN-D for the validation cohort. Women

168 participating in WHI were recruited from 40 clinical centers in the United States. Serum 25(OH)D was

169 measured as part of the Calcium and Vitamin D (CaD) Trial (51). WHI data were obtained through dbGaP

170 Study Accession: phs000200.v11.p3. Participants were included if they had the minimum set of variables:

171 genome-wide data, serum 25(OH)D, age, sex, BMI, and month of blood draw. WHI provided data on 455

172 European- and 700 African-ancestry participants for the validation cohort. Thus, together, in the validation

173 cohort, the European-ancestry sample included 8,569 participants and the African-ancestry sample

174 included 1,042 participants.

175

Datasets used for heritability estimation

$178(n=7,119)$ and African $(n=1,719)$ ancestry from ARIC.

179 Participant consent was previously obtained for each study providing data; additionally, IRB

180 approval was granted for this specific mega-analysis. 
Data cleaning for phenotypic data included winsorizing 25(OH)D in the MESA and WHI samples

184 to account for outliers (52). In the WHI sample, participants with 25(OH)D values far above the maximum 185 level of detection (150 ng/mL), none of which had extreme vitamin $D$ intake (including supplement use) or 186 sun exposure, were removed from the sample; this included 68 participants of European ancestry and 187119 participants of African ancestry. All 25(OH)D values were log transformed to improve the normality of 188 the distribution in each cohort.

Genotyping methods are available in Supplemental Table 1 and described in more detail elsewhere (53-57). In summary, QC removed: sex mismatches, samples and SNPs with high

191 missingness $(>5 \%)$, SNPs with low minor allele frequency $(\mathrm{MAF}<0.2 \%)$, and SNPs out of Hardy-Weinberg 192 equilibrium (HWE<0.05/number of SNPs; Bonferroni adjusted cut-off). Datasets were imputed using the

193 Michigan Imputation Server $(58,59)$. European samples were imputed to the Haplotype Reference

194 Consortium (HRC) and African samples were imputed to the Consortium on Asthma among African195 ancestry Populations in the Americas (CAAPA) (59,60). Post imputation QC included: removing SNPs

196 with a low quality score $(<0.8)$ or MAF $(<0.1 \%)$. Additionally, sample and SNP level missingness as well 197 as HWE cutoffs were rechecked. Supplemental Figures 1-2 and Supplemental Table 1 give specifics on 198 quality control for each cohort. QC was performed using PLINK v1.9 and vcfTools $(61,62)$. Ancestry was 199 determined by self-reported data and confirmed with principal components analysis (PCA) in PLINK using 2001000 Genomes data as anchoring populations (63).

Measurement of $25(\mathrm{OH}) \mathrm{D}$

Blood 25(OH)D concentration was measured by the studies using different assay types. WHI 205 used the DiaSorin LIASON chemiluminescence, while both MESA and ARIC used liquid chromatography206 mass spectrometry (LCMS), which is considered the gold standard for 25(OH)D measurement $(64,65)$.

207 Vitamin D concentration $[25(\mathrm{OH}) \mathrm{D}]$ was log transformed to improve normality of the distribution. To 208 control for differences in vitamin D concentrations due to different assays, $25(\mathrm{OH}) \mathrm{D}$ concentrations were 209 converted to z-scores within studies for combined cohort analyses. 
Measurement of vitamin D intake

211 Dietary data were collected via questionnaire. Each study used their own questionnaire. WHI

212 used the Food Frequency Questionnaire supplemented with interview questions. ARIC and MESA both

213 used their own implementation of a food intake questionnaire. From the questionnaire data, each study

214 created a derived variable of typical vitamin D intake (measured in IU or mcg). All values were converted

215 to IU for analysis. Additionally, WHI collected data on vitamin D supplement use at the same visit that

$21625(\mathrm{OH}) \mathrm{D}$ was assessed. The sum of vitamin D intake from food and supplements was calculated and

217 used for supplemental and sensitivity analyses, otherwise dietary intake alone was used.

219 Calculation of available UV radiation

220 Available UV radiation was calculated based on the month of blood draw and location;

221 participants were assigned continuous available UV radiation values. Available UV radiation values

222 assigned were an average UV-index for the month prior to blood draw (the relevant exposure period). UV

223 data come from the National Weather Service Climate Prediction Center historical database. When

224 available, UV radiation values corresponded to the exact location and year of the participant's blood draw.

225 When exact cities or years were not available, averages across nearby locations or years were used. See

226 Supplemental Tables 2-4 for specific month, year and location values used. Descriptive statistics for

227 available UV radiation values by site and month are also presented in Supplemental Tables 5-7; the UV

228 radiation values ranged from 0.7 to $9.5 \mathrm{UV}$ Index units.

Determining optimal PGS

An optimal p-value cutoff and corresponding PGS were determined by calculating PGSs across a

233 wide range of $p$-value thresholds and testing the association between the PGS and $\log [25(\mathrm{OH}) \mathrm{D}]$ in the

234 target/tuning dataset. First, summary statistics were attained from TRANSCEN-D, the base dataset

$235(1,37)$, which included SNPS with MAF > 0.01 and tested them for association with $\log [25(\mathrm{OH}) \mathrm{D}]$ using an

236 additive genetic model adjusting for age, sex, BMI, UV index and principal components (PCs) 1-10. PGSs 
237 were then calculated in PRSice v2, which computes the sum of reference allele counts at each SNP 238 weighted by the effect size ( $\beta$ ) for that SNP from the TRANSCEN-D consortium (43). PGS weights came

239 from ancestry-specific z-scores from TRANSCEN-D that were converted to betas with the deterministic

240 relationship: $\beta=z /(\operatorname{sqrt}(2 p(1-p) * N))$, where $p$ is the allele frequency for the reference SNP (66). One

241 tuning parameter in PGS development is the LD cutoff used for clumping to prevent SNPs in one

242 correlated region from dominating the PGS. Here, PGSs were calculated in the target/tuning dataset

243 using two different LD cut-offs, $r^{2} \geq 0.5$ or $\geq 0.2$, keeping the SNP with the strongest effect in the base

244 dataset. SNPs in LD with one another were clumped, using the --clump-r2 option in PRSice v2. The LD

245 cutoff that yielded the PGS that explains the most variance in 25(OH)D was used in downstream

246 analyses. Given the small African-ancestry sample, a reference panel (remaining ARIC African-ancestry

247 dataset $n=1,900$ ) was used to determine $L D$.

248 To determine which set of SNPs to include in the PGS, SNPs at or below a given p-value

249 threshold in the base dataset were included in the PGS and tested in a linear regression model for

250 association with $\log \left[25(\mathrm{OH}) \mathrm{D}\right.$ in the target/tuning dataset]. P-value thresholds from $5 \times 10^{-5}-0.5$ were tested

251 incrementing by $5 \times 10^{-5}$ at each iteration (supplemental testing using a p-value threshold of 1.0 was

252 performed). All testing was done using PRSice v2 (43). The threshold with the PGS explaining the most

253 variance in $\log [25(\mathrm{OH}) \mathrm{D}]$ was selected as the most optimal PGS. $\mathrm{R}^{2}$, or the coefficient of determination,

254 was calculated to measure the proportion of phenotypic variance explained by the model. Linear

255 regression models were used to calculate the $\mathrm{R}^{2}$ of a given PGS while controlling for participant age, sex,

256 BMI, available UV radiation, and PCs for ancestry. Five PCs were controlled for in the African-ancestry

257 models and two PCs in the European-ancestry models, as determined based on the 'elbow' of cohort-

258 and ancestry-specific scree plots. Sensitivity analysis was performed including dietary intake in the model,

259 as dietary intake is a strong predictor of $25(\mathrm{OH}) \mathrm{D}$ concentrations. However, with the inclusion of dietary

260 intake in the model, the optimal PGS (and p-value cutoff) remained the same for the European cohort, but

261 reduced sample size substantially in the African-ancestry cohort. Therefore, to maintain sample size,

262 dietary intake was not included in the model to determine the optimal p-value cutoff (Supplemental Table

263 8). 
PGS performance validation

PGS performance was validated in an ancestry-specific manner using participants in validation cohorts, which were combined cohorts of samples from ARIC, MESA, and WHI that maintained

269 independence from TRANSCEN-D and PGS development samples. The PGS was applied to the 270 participants in the validation dataset in accordance with the ancestry specific $p$-value cutoff. The

271 relationship between PGS quantile and 25(OH)D was tested using a linear regression model controlling 272 for age, sex, BMI, available UV radiation, and PCs for ancestry. Quantile plots were created depicting the

273 relationship between PGS decile and 25(OH)D concentration. Sensitivity analyses were performed to 274 ensure that the study design of the WHI CaD randomized control trial was not biasing the results.

The African-ancestry target/tuning cohort was small $(n=57)$ due to limited genome-wide data in

278 those of African ancestry. To explore if the small sample reduced prediction for those of African ancestry,

279 a PGS was created from all independent SNPs ( $p$-value cutoff $=1.0 ; r^{2}$ cutoff $=0.5$ ) in the full

280 independent sample of African-ancestry participants which maintained independence from TRANSCEN-D $281(n=1,099)(67)$. Additionally, to test the importance of ancestrally-matched base and target sets, this PGS was also created using European-ancestry GWAS summary statistics for weighting of the PGS.

\section{Heritability Estimation}

Heritability estimates were calculated using GCTA v1.26 (68). Heritability was estimated several

287 ways: (1) ancestry-specific overall SNP heritability, (2) ancestry-specific SNP heritability of the PGS

288 (where sample size allowed) and (3) ancestry-specific SNP heritability of previous replicated GWAS

289 findings in CYP2R1, CYP24A1, DHCR7, and GC $(1,34,37)$. In each case, the model was adjusted for 290 age, sex, BMI, available UV, and dietary vitamin D intake.

291 SNP heritability estimates were calculated using all genotyped and imputed SNPs for both the

292 European and African ancestry populations from ARIC; this was 8,315,761 and 9,335,785 SNPS, 293 respectively. Partitioned heritability estimates were discerned paralleling methodology described by the 
294 SUNLIGHT consortium (36). To estimate heritability captured by the PGS, heritability was calculated

295 twice; once using the clumped set of SNPs used to determine the PGS $(228,867$ SNPs for European

296 ancestry and 850,697 for African ancestry) and a second time using the clumped set of SNPs with SNPs

297 included in the PGS removed (228,526 SNPs for European ancestry and 818,428 for African ancestry).

298 The difference in heritability estimates between these two models was the heritability explained by the

299 PGS. Heritability could not be directly calculated from the SNPs in the PGS because one of the

300 assumptions made by the GCTA modeling is an average null effect of the SNPs on the outcome. Of note,

301 the African-ancestry sample was too small for this analysis to be valid, so heritability attributed to the PGS

302 was only calculated in those of European ancestry. In discerning the heritability captured by previous

303 replicated GWAS studies, heritability was calculated using a reduced set of SNPs: the full genotyped and

304 imputed set with top GWAS findings (and SNPs in the surrounding LD block) removed $(36,69)$. The

305 difference between this estimate and the overall heritability estimates was the heritability attributed to

306 previous replicated GWAS findings. Additionally, a second heritability estimate was calculated that

307 included novel findings. This included SNPs from AMDHD1 and SEC23A in those of European ancestry

308 and SNPs from KIF4B, HTR2A and ANO6/ARID2 in those of African ancestry $(36,37)$. Table 1

309 summarizes the SNPs and LD blocks removed in each scenario. LD block size was determined using the

310 Plots mode of the SNAP tool by the Broad (69). All models were fit separately for European and African

311 ancestry samples.

\section{Results}

314 Determining the optimal PGS

Table 2 shows sample characteristics for each analysis. Table 3 shows statistics for the best

317 performing PGS for each ancestry in the target/tuning and validation datasets while controlling for age,

318 sex, BMI, available UV radiation, and PCs for ancestry. In both ancestries, the PGS using the LD cut-off

319 of 0.5 was more strongly associated with and explained more of the variance in $\log [25(\mathrm{OH}) \mathrm{D}]$ than did the

320 PGS using the LD cut-off of 0.2 (Supplemental Table 9). Therefore, this was the LD cutoff utilized going

321 forward. In the European-ancestry analyses, the optimal PGS explained $1.4 \%$ of the variance in 
$322 \log [25(\mathrm{OH}) \mathrm{D}]\left(\mathrm{p}=9.3 \times 10^{-5}\right)$ in the target/tuning dataset and $1.0 \%$ of the variance $\left(p=1.1 \times 10^{-23}\right)$ in the

323 validation cohort. In the African-ancestry analyses, the PGS explained $2.9 \%$ of the variance in

$324 \log [25(\mathrm{OH}) \mathrm{D}](\mathrm{p}=0.11)$ in the target/tuning dataset and $0.2 \%$ of the variance $(p=0.15)$ in the validation

325 cohort. Of note, the optimally performing PGS in the African-ancestry target/tuning dataset contained

326 many more SNPs than that from the European-ancestry dataset, mostly due to the less stringent $p$-value

327 cutoff, but also because a larger number of SNPs remained post clumping $(850,697$ vs 228,867$)$ due to

328 smaller LD blocks in the African-ancestry sample and more input SNPs from the TRANSCEN-D summary

329 statistics (8.4 million in the African-ancestry vs 1.2 million in the European-ancestry sample). Figure 1

330 depicts the results visually, where a taller bar corresponds to a larger percent of the phenotypic variance

331 explained by the PGS.

332 In supplementary analyses for the African-ancestry cohort, the PGS using the full African-

333 ancestry sample that was independent from TRANSCEN-D $\left(n=1,099 ; p\right.$-value cutoff $=1.0 ; r^{2}$ cutoff $\left.=0.5\right)$

334 explained more variance $(0.31 \%$ vs $0.2 \%)$ and had a stronger association ( $p=0.0545$ vs 0.15$)$ than the

335 optimal PGS determined from PRSice using the small tuning cohort $(n=57)$ and larger validation cohort

336 ( $n=1042)$, therefore this PGS was chosen as most optimal and used moving forward. In additional

337 analyses to test the importance of ancestrally-matched base and target sets, the PGS (p-value cutoff =

$3381.0 ; r^{2}$ cutoff $\left.=0.5\right)$ developed from European-ancestry TRANSCEN-D summary statistics only explained

$3390.14 \%$ of the variance $(p=0.1897$; worse performance than the PGS developed from African-ancestry

340 TRANSCEN-D summary statistics that explained $0.31 \%$ of the variance in $25(\mathrm{OH}) \mathrm{D}[\mathrm{p}=0.0545])$. Results

341 are shown in Table 3 and Supplemental Table 10.

After the optimal, ancestry-specific PGS was discerned, the relationship between the PGS and

$34325(\mathrm{OH}) \mathrm{D}$ was investigated using ancestry-specific combined cohorts of samples from ARIC, MESA and

344 WHI, which maintained independence from the TRANSCEN-D (and tuning, for those of European

345 ancestry) samples. Characteristics of these samples are summarized in Table 2. Figures 2 and 3 show

346 ancestry-specific plots for $25(\mathrm{OH}) \mathrm{D}$ by decile of the PGS. In general, those with greater genetic risk (lower

347 PGS and quantile) have lower 25(OH)D concentrations. For a clinically-based interpretation, in the

348 European validation cohort (Figure 2, $n=8,569$ ), those with the lowest PGS have vitamin D concentrations

$3493.0 \mathrm{ng} / \mathrm{ml}$ lower than those with the highest PGS $\left(p=3.2 \times 10^{-13}\right)$. Figure 3 shows the trend for those of 
350 African ancestry ( $n=1,099$; combined tuning and validation samples from Table 2); those with the lowest

351 PGS have vitamin D concentrations $2.8 \mathrm{ng} / \mathrm{ml}$ lower than those with the highest PGS $(p=0.0463)$. Results

352 from the PGS determined using the separate tuning and validation cohorts are included in Supplemental

353 Figure 3.

354 Sensitivity analyses showed there was no significant difference in 25(OH)D concentration

355 between participants on the treatment arm compared to the placebo arm in the participants from WHI.

356 Additionally, there was no significant difference in PGS-25(OH)D trend in WHI compared to the other

357 cohorts.

Heritability estimation

Participant characteristics are summarized in Table 2. Overall and stratified SNP heritability estimates for those of European or African ancestry are summarized in Figure 4 and Supplemental Figure

3634 , respectively. SNP heritability is higher in the African-ancestry cohort compared to the European-

364 ancestry cohort ( $32 \%$ vs $22 \%$; standard errors 17.8 and 5.2 , respectively $(p=0.49)$. In those of European 365 ancestry, the PGS accounts for $17.1 \%$ (3.7/21.6) of the SNP heritability of 25(OH)D concentrations and 366 previous replicated GWAS findings (i.e., SNPs from CYP2R1, CYP24A1, DHCR7 and GC) account for

$3676.9 \%(1.5 / 21.6)$ of the total SNP heritability $(1,34,37)$. In those of African ancestry, these same top GWAS 368 findings accounted for only $1.6 \%(0.5 / 32.2)$ of the total SNP heritability. Heritability accounted for by 369 previous GWAS findings remained unchanged when ancestry-specific novel findings were included in the 370 heritability estimations $(1,34,36,37)$. African-ancestry sample size was too small to calculate heritability 371 accounted for by the PGS.

\section{Discussion}

Vitamin $D$ inadequacy is a pervasive health problem, with a strong genetic basis. However, to 376 date, much of the heritability of $25(\mathrm{OH}) \mathrm{D}$ remains unexplained. Furthermore, there is a tremendous gap in 377 the research carried out in minority ancestries compared to European ancestry. Filling these knowledge 378 gaps is critical in preventive care to manage $25(\mathrm{OH}) \mathrm{D}$ concentration, especially as we move towards 
379 precision medicine, and development of an ancestry-specific PGS is one way to address these gaps. To 380 date, across all phenotypes, most PGS have been calculated in those of European ancestry. A handful of 381 studies have begun to explore ancestry-specific PGS, however, none of these approaches utilize an 382 entirely ancestry-specific approach as was undertaken here (70-72). Given the underlying genetic 383 difference between ancestries (i.e., different LD patterns and allele frequencies), an ancestry-specific 384 approach is more appropriate. Calculating PGSs using GWAS summary statistics from an ancestry385 matched population accounts for differences in linkage disequilibrium (LD) and allele frequencies that 386 exist between ancestral groups leading to differences in allele effect sizes, which are used as weights in 387 the PGS calculation. Here, optimal PGSs were discerned and validated in an ancestry-specific manner. 388 Heritability explained by the PGS and previous GWAS findings was compared to overall SNP heritability. The relationship between the PGS and 25(OH)D concentrations was consistent across ancestries 390 in the validation cohorts, albeit modest variance was explained by the PGS; those with the lowest PGS 391 (most risk) had the lowest 25(OH)D concentrations. Moving from the highest to lowest quantile changed $39225(\mathrm{OH}) \mathrm{D}$ concentrations by $2.8-3.0 \mathrm{ng} / \mathrm{ml}$, a statistically significant and clinically meaningful difference.

393 One study reported that for each additional $100 \mathrm{IU}$ of vitamin D consumed, serum 25(OH)D levels

394 increased by $0.6 \mathrm{ng} / \mathrm{ml}$ (73). Using this conversion, compared to those with lowest genetic risk, those with 395 highest genetic risk could require an additional 467 to $500 \mathrm{IU}$ of vitamin D to maintain comparable levels.

396 While the small sample used to determine the p-value cut-off in those of African ancestry could have led 397 to overfitting of the model, the consistent direction of effect between PGS quantile and 25(OH)D 398 concentrations suggests clinical utility for a 25(OH)D PGS to inform vitamin D supplementation in those 399 with high genetic risk for $25(\mathrm{OH}) \mathrm{D}$ inadequacy. The portion of phenotypic variance explained by the PGS was modest due to many concurrent 401 influences. First, the PGS did not include rare variants (MAF < 0.01) as they were removed from the base 402 set (TRANSCEN-D). Common SNPs account for only a small proportion of genetic variance in complex 403 traits (38). Future PGSs that include rare variants will likely account for a greater portion of the variance. 404 Additionally, the variance that the PGS can capture is limited by the input SNPs. In the best-case 405 scenarios (i.e. densest chips), the overlap between the SNPs in the base and target datasets was $4063,520,049$ and 1,026,643 SNPs, for African and European ancestries, respectively. While over 1 million 
407 SNPs can be very informative, much of the genome was not included. Thirdly, PRSice implements

408 clumping which keeps only the SNP with the strongest association for SNPs in LD $\left(r^{2}>0.5\right.$ used here $)$ in

409 any given $500 \mathrm{~kb}$ window, thus reducing the maximum variability that could be captured by a PGS.

410 Supplementary analyses performed in the full independent sample of African ancestry

411 participants $(n=1,099)$ demonstrated (1) the importance of a large tuning sample and (2) the importance

412 of ancestrally-matched base and target sets. Comparing the results from the small tuning sample $(n=57)$

413 and the analysis using the full independent sample of African-ancestry participants $(n=1,099)$, more

414 variance, $0.3 \%$ compared to $0.2 \%$, was accounted for, and the association between PGS and $25(\mathrm{OH}) \mathrm{D}$

415 was stronger ( $p=0.0545$ vs 0.15$)$ using the PGS developed in the full sample $(n=1,099)$. Additionally,

416 variance accounted for dropped to $0.14 \%$ (compared to $0.31 \%$ ) and the PGS-25(OH)D association

417 became non-significant $(p=0.19)$ when using mismatched summary statistics, reiterating the importance

418 of ancestry-specific analyses.

419 Not surprisingly, the heritability investigation provided further evidence that PGSs using a less

420 stringent $p$-value threshold account for a higher portion of the heritability than genome-wide significant

421 SNPs from previous GWAS. Here, the PGS explained more of the SNP heritability than did previous

422 GWAS findings, $17.1 \%$ compared to $6.9 \%$ in those of European ancestry (sample size was too small for

423 PGS heritability calculations in those of African ancestry). However, neither the PGS nor previous GWAS

424 findings explain a large portion of total SNP heritability, promoting the need for genetic studies with larger

425 sample sizes and more dense SNP data that include low frequency variants to fully understand the

426 genetic determinants of $25(\mathrm{OH}) \mathrm{D}$ concentrations and, therefore, inform the most effective vitamin $\mathrm{D}$

427 supplementation practices.

428 This study calculated a PGS with a moderate $\mathrm{R}^{2}$, a consistent relationship to $25(\mathrm{OH}) \mathrm{D}$

429 concentrations and that explained more heritability of $25(\mathrm{OH}) \mathrm{D}$ than previous GWAS findings, reiterating

430 the importance of capturing genetic risk by PGS which can be used for clinical predictions. Additionally,

431 this study contributes in-depth multi-ethnic investigation into $25(\mathrm{OH}) \mathrm{D}$ heritability by ancestry, teasing

432 apart genetic underpinnings of $25(\mathrm{OH}) \mathrm{D}$ concentrations. However, the study does come with some

433 limitations. To maintain independence from TRANSCEN-D, which provided ancestry-specific weights for

434 the PGSs, the sample size used in this analysis was relatively small, especially for the African-ancestry 
435 cohort. The sample size issues experienced for the African-ancestry cohort emphasize the importance of 436 obtaining more diverse samples (i.e. in initiatives like All of Us) (74). Through the TRANSCEN-D GWAS

437 meta-analysis and the analysis here, nearly all of the publicly available African-ancestry samples with

438 relevant data have been exhausted and sample sizes for other racial/ethnic groups remain limited. The

439 limited amount of diverse data led to a small African-ancestry training set. A small training set limits

440 discrimination of risk groups which could explain the less significant findings for those of African ancestry

441 (42). Furthermore, the genotyping performed did not capture rare variants, limiting the variance that could

442 be captured by the PGS. While GCTA allows for the calculation of heritability in non-related participants,

443 which avoids overestimation due to shared environment, it only accounts for additive SNP effects,

444 potentially underestimating total heritability which also could include gene-by-gene interactions. Finally,

445 while adjusting for available UV radiation is more precise than season, it is not a perfect proxy for time

446 spent outside and does not consider the amount of skin exposed, sunscreen use or skin pigmentation.

447 These limitations leave room for future studies and replication that should be performed. For example,

448 future PGSs could be developed implementing the recent cross-prediction method developed by Mak

449 et,al; this method allows and corrects for overlap between the base and target dataset that would have

450 allowed for a much larger African-ancestry sample (75). Additionally, in the future, the PGS could be

451 utilized as an independent variable to predict health outcomes.

This study showed that PGSs are a powerful predictive tool for determining $25(\mathrm{OH}) \mathrm{D}$

456 concentrations. Given the association between the optimal PGS and 25(OH)D concentrations, PGSs

457 could be leveraged for personalized vitamin D supplementation, which could prevent the negative

458 downstream effects of 25(OH)D inadequacy. Additionally, through an in-depth investigation of 25(OH)D

459 SNP heritability, it was shown that the PGS explains more heritability than do GWAS findings to date.

460 This provides additional evidence that many SNPs that function through small effect sizes influence

$46125(\mathrm{OH}) \mathrm{D}$ concentrations, yielding further understanding of the genetic architecture of 25(OH)D. However

462 much of the heritability remains to be explained, therefore, more research is warranted along the quest to

463 effectively and efficiently preventing $25(\mathrm{OH}) \mathrm{D}$ inadequacy through personalized supplementation. 
bioRxiv preprint doi: https://doi.org/10.1101/596619; this version posted April 4, 2019. The copyright holder for this preprint (which was not certified by peer review) is the author/funder, who has granted bioRxiv a license to display the preprint in perpetuity. It is made available under aCC-BY-ND 4.0 International license.

\section{Appendix}




\section{Acknowledgments}

We thank the researchers and participants of Atherosclerosis in Communities (ARIC), Multi-Ethnic Study of Atherosclerosis and the Women's Health Initiative (WHI) for making this data publicly available.

$\underline{\text { ARIC }}$

The Atherosclerosis Risk in Communities Study is carried out as a collaborative study supported by National Heart, Lung, and Blood Institute contracts (HHSN268201100005C, HHSN268201100006C, HHSN268201100007C, HHSN268201100008C, HHSN268201100009C, HHSN268201100010C, HHSN268201100011C, and HHSN268201100012C). The authors thank the staff and participants of the ARIC study for their important contributions.

Funding for GENEVA was provided by National Human Genome Research Institute grant U01HG004402 (E. Boerwinkle). Vitamin D assays in ARIC were funded by R01 HL103706 (P. Lutsey).

\section{$\underline{M E S A}$}

MESA and the MESA SHARe project are conducted and supported by the National Heart, Lung, and Blood Institute (NHLBI) in collaboration with MESA investigators. Support for MESA is provided by contracts HHSN268201500003I, N01-HC-95159, N01-HC-95160, N01-HC-95161, N01-HC-95162, N01HC-95163, N01-HC-95164, N01-HC-95165, N01-HC-95166, N01-HC-95167, N01-HC-95168, N01-HC95169, UL1-TR-000040, UL1-TR-001079, UL1-TR-001420, UL1-TR-001881, and DK063491.

The MESA CARe data used for the analyses described in this manuscript were obtained through Genetics (accession numbers). Funding for CARe genotyping was provided by NHLBI Contract N01-HC65226.

490 Funding support for the Vitamin D dataset was provided by grant HL096875

$\underline{\mathrm{WHI}}$

The WHI program is funded by the National Heart, Lung, and Blood Institute, National Institutes of Health, U.S. Department of Health and Human Services through contracts HHSN268201600018C, HHSN268201600001C, HHSN268201600002C, HHSN268201600003C, and HHSN268201600004C. This manuscript was not prepared in collaboration with investigators of the WHI, has not been reviewed and/or approved by the Women's Health Initiative (WHI), and does not necessarily reflect the opinions of the $\mathrm{WHI}$ investigators or the NHLBI.

WHI PAGE is funded through the NHGRI Population Architecture Using Genomics and Epidemiology (PAGE) network (Grant Number U01 HG004790). Assistance with phenotype harmonization, SNP selection, data cleaning, meta-analyses, data management and dissemination, and general study coordination, was provided by the PAGE Coordinating Center (U01HG004801-01).

511

Funding support for WHI GARNET was provided through the NHGRI Genomics and Randomized Trials Network (GARNET) (Grant Number U01 HG005152). Assistance with phenotype harmonization and genotype cleaning, as well as with general study coordination, was provided by the GARNET Coordinating Center (U01 HG005157). Assistance with data cleaning was provided by the National Center for Biotechnology Information. Funding support for genotyping, which was performed at the Broad Institute of MIT and Harvard, was provided by the NIH Genes, Environment and Health Initiative [GEI] (U01 HG004424). 
bioRxiv preprint doi: https://doi org/10.1101/596619; this version posted April 4,2019. The copyright holder for this preprint (which was not certified by peer review) is the author/funder, who has granted bioRxiv a license to display the preprint in perpetuity. It is made available under aCC-BY-ND 4.0 International license.

512 The datasets used for the analyses described in this manuscript were obtained from dbGaP at

513 http://www.ncbi.nlm.nih.gov/sites/entrez?db=gap through dbGaP accession phs000200.v11.p3.

514

515 Funding for WHI SHARe genotyping was provided by NHLBI Contract N02- HL-64278.

516

517 KEH was supported by an NLM training grant to the Computation and Informatics in Biology and Medicine 518 Training Program (NLM 5T15LM007359). Computational resources were supported by a core grant to the 519 Center for Demography and Ecology at the University of Wisconsin-Madison (P2C HD047873). 


\section{References}

522

523

524

525

526

527

528

1. Wang TJ, Zhang F, Richards JB, Kestenbaum B, van Meurs JB, Berry D, Kiel D, Streeten EA, Ohlsson C, Koller DL, Palotie L, Cooper JD, O'Reilly PF, Houston DK, Glazer NL, Vandenput L, Peacock M, Shi J, Rivadeneira F, McCarthy MI, Anneli P, de Boer IH, Mangino M, Kato B, Smyth DJ, Booth SL, Jacques PF, Burke GL, Goodarzi M, Cheung C-L, Wolf M, Rice K, Goltzman D, Hidiroglou N, Ladouceur M, Hui SL, Wareham NJ, Hocking LJ, Hart D, Arden NK, Cooper C, Malik S, Fraser WD, Hartikainen A-L, Zhai G, Macdonald H, Forouhi NG, Loos RJF, Reid DM, Hakim A, Dennison E, Liu Y, Power C, Stevens HE, Jaana L, Vasan RS, Soranzo N, Bojunga J, Psaty BM, Lorentzon M, Foroud T, Harris TB, Hofman A, Jansson J-O, Cauley JA, Uitterlinden AG, Gibson Q, Järvelin M-R, Karasik D, Siscovick DS, Econs MJ, Kritchevsky SB, Florez JC, Todd JA, Dupuis J, Hypponen E, Spector TD. Common genetic determinants of vitamin D insufficiency: a genome-wide association study. Lancet 2010; 376:180-188

2. Forrest KYZ, Stuhldreher WL. Prevalence and correlates of vitamin D deficiency in US adults. Nutrition Research 31:48-54

3. Medicine lo. Dietary Reference Intakes for Calcium and Vitamin D. Washington, DC: The National Academies Press.

4. Holick MF. High Prevalence of Vitamin D Inadequacy and Implications for Health. Mayo Clinic Proceedings 81:353-373

5. Holick MF. Vitamin D Deficiency. New England Journal of Medicine 2007; 357:266-281

6. Mirhosseini N, Vatanparast H, Kimball SM. The Association between Serum 25(OH)D Status and Blood Pressure in Participants of a Community-Based Program Taking Vitamin D Supplements. Nutrients 2017; 9:1244

7. Arshi S, Fallahpour M, Nabavi M, Bemanian MH, Javad-Mousavi SA, Nojomi M, Esmaeilzadeh $\mathrm{H}$, Molatefi R, Rekabi M, Jalali F, Akbarpour N. The effects of vitamin D supplementation on airway functions in mild to moderate persistent asthma. Annals of Allergy, Asthma \& Immunology 2014; 113:404-409

8. Song T-J, Chu M-K, Sohn J-H, Ahn H-Y, Lee SH, Cho S-J. Effect of Vitamin D Deficiency on the Frequency of Headaches in Migraine. Journal of Clinical Neurology (Seoul, Korea) 2018; 14:366373

9. Kheiri B, Abdalla A, Osman M, Ahmed S, Hassan M, Bachuwa G. Vitamin D deficiency and risk of cardiovascular diseases: a narrative review. Clinical Hypertension 2018; 24:9

10. Kunutsor SK, Burgess S, Munroe PB, Khan H. Vitamin D and high blood pressure: causal association or epiphenomenon? European Journal of Epidemiology 2014; 29:1-14

11. Afzal S, Brøndum-Jacobsen P, Bojesen SE, Nordestgaard BG. Genetically low vitamin D concentrations and increased mortality: mendelian randomisation analysis in three large cohorts. BMJ 2014; 349

12. Mokry LE, Ross S, Ahmad OS, Forgetta V, Smith GD, Leong A, Greenwood CMT, Thanassoulis G, Richards JB. Vitamin D and Risk of Multiple Sclerosis: A Mendelian Randomization Study. PLoS Med 2015; 12:e1001866

13. Ong J-S, Cuellar-Partida G, Lu Y, Fasching PA, Hein A, Burghaus S, Beckmann MW, Lambrechts D, Van Nieuwenhuysen E, Vergote I, Vanderstichele A, Anne Doherty J, Anne Rossing M, Chang-Claude J, Eilber U, Rudolph A, Wang-Gohrke S, Goodman MT, Bogdanova N, Dörk T, Dürst M, Hillemanns P, Runnebaum IB, Antonenkova N, Butzow R, Leminen A, Nevanlinna H, Pelttari LM, Edwards RP, Kelley JL, Modugno F, Moysich KB, Ness RB, Cannioto R, Høgdall E, Høgdall CK, Jensen A, Giles GG, Bruinsma F, Kjaer SK, Hildebrandt MAT, Liang D, Lu KH, Wu X, Bisogna M, Dao F, Levine DA, Cramer DW, Terry KL, Tworoger SS, Stampfer M, Missmer S, Bjorge L, Salvesen HB, Kopperud RK, Bischof K, Aben KKH, Kiemeney LA, Massuger LFAG, Brooks-Wilson A, Olson SH, McGuire V, Rothstein JH, Sieh W, Whittemore AS, Cook LS, Le ND, Gilks CB, Gronwald J, Jakubowska A, Lubiński J, Kluz T, Song H, Tyrer JP, Wentzensen N, Brinton L, Trabert B, Lissowska J, McLaughlin JR, Narod SA, Phelan C, AntonCulver H, Ziogas A, Eccles D, Campbell I, Gayther SA, Gentry-Maharaj A, Menon U, Ramus SJ, Wu AH, Dansonka-Mieszkowska A, Kupryjanczyk J, Timorek A, Szafron L, Cunningham JM, Fridley BL, Winham SJ, Bandera EV, Poole EM, Morgan TK, Risch HA, Goode EL, Schildkraut JM, Pearce CL, Berchuck A, Pharoah PDP, Chenevix-Trench G, Gharahkhani P, Neale RE, 
Webb PM, MacGregor S. Association of vitamin D levels and risk of ovarian cancer: a Mendelian randomization study. International Journal of Epidemiology 2016; 45:1619-1630

14. Vimaleswaran KS, Cavadino A, Berry DJ, LifeLines Cohort Study i, Jorde R, Dieffenbach AK, Lu C, Alves AC, Heerspink HJL, Tikkanen E, Eriksson J, Wong A, Mangino M, Jablonski KA, Nolte IM, Houston DK, Ahluwalia TS, van der Most PJ, Pasko D, Zgaga L, Thiering E, Vitart V, Fraser RM, Huffman JE, de Boer RA, Schöttker B, Saum K-U, McCarthy MI, Dupuis J, Herzig K-H, Sebert S, Pouta A, Laitinen J, Kleber ME, Navis G, Lorentzon M, Jameson K, Arden N, Cooper JA, Acharya J, Hardy R, Raitakari O, Ripatti S, Billings LK, Lahti J, Osmond C, Penninx BW, Rejnmark L, Lohman KK, Paternoster L, Stolk RP, Hernandez DG, Byberg L, Hagström E, Melhus H, Ingelsson E, Mellström D, Ljunggren Ö, Tzoulaki I, McLachlan S, Theodoratou E, Tiesler CMT, Jula A, Navarro P, Wright AF, Polasek O, International Consortium for Blood Pressure $\mathrm{CfH}$, Aging Research in Genomic Epidemiology consortium GBPGc, Hayward C, Wilson JF, Rudan I, Salomaa V, Heinrich J, Campbell H, Price JF, Karlsson M, Lind L, Michaëlsson K, Bandinelli S, Frayling TM, Hartman CA, Sørensen TIA, Kritchevsky SB, Langdahl BL, Eriksson JG, Florez JC, Spector TD, Lehtimäki T, Kuh D, Humphries SE, Cooper C, Ohlsson C, März W, de Borst MH, Kumari M, Kivimaki M, Wang TJ, Power C, Brenner H, Grimnes G, van der Harst P, Snieder H, Hingorani AD, Pilz S, Whittaker JC, Järvelin M-R, Hyppönen E. Association of vitamin $\mathrm{D}$ status with arterial blood pressure and hypertension risk: a mendelian randomisation study. The lancet Diabetes \& endocrinology 2014; 2:719-729

15. Kueider AM, Tanaka T, An Y, Kitner-Triolo MH, Palchamy E, Ferrucci L, Thambisetty M. Stateand trait-dependent associations of vitamin-D with brain function during aging. Neurobiology of Aging 2016; 39:38-45

16. Vimaleswaran KS, Berry DJ, Lu C, Tikkanen E, Pilz S, Hiraki LT, Cooper JD, Dastani Z, Li R, Houston DK, Wood AR, Michaëlsson K, Vandenput L, Zgaga L, Yerges-Armstrong LM, McCarthy MI, Dupuis J, Kaakinen M, Kleber ME, Jameson K, Arden N, Raitakari O, Viikari J, Lohman KK, Ferrucci L, Melhus H, Ingelsson E, Byberg L, Lind L, Lorentzon M, Salomaa V, Campbell H, Dunlop M, Mitchell BD, Herzig K-H, Pouta A, Hartikainen A-L, the Genetic Investigation of Anthropometric Traits c, Streeten EA, Theodoratou E, Jula A, Wareham NJ, Ohlsson C, Frayling TM, Kritchevsky SB, Spector TD, Richards JB, Lehtimäki T, Ouwehand WH, Kraft P, Cooper C, März W, Power C, Loos RJF, Wang TJ, Järvelin M-R, Whittaker JC, Hingorani AD, Hyppönen E. Causal Relationship between Obesity and Vitamin D Status: Bi-Directional Mendelian Randomization Analysis of Multiple Cohorts. PLoS Medicine 2013; 10:e1001383

17. Boonen S, Lips P, Bouillon R, Bischoff-Ferrari HA, Vanderschueren D, Haentjens P. Need for Additional Calcium to Reduce the Risk of Hip Fracture with Vitamin D Supplementation: Evidence from a Comparative Metaanalysis of Randomized Controlled Trials. The Journal of Clinical Endocrinology \& Metabolism 2007; 92:1415-1423

18. Schnatz PF, Jiang X, Aragaki AK, Nudy M, O'Sullivan DM, Williams M, LeBlanc ES, Martin LW, Manson JE, Shikany JM, Johnson KC, Stefanick ML, Payne ME, Cauley JA, Howard BV, Robbins J. Effects of Calcium, Vitamin D, and Hormone Therapy on Cardiovascular Disease Risk Factors in the Women's Health Initiative: A Randomized Controlled Trial. Obstetrics and gynecology 2017; 129:121-129

19. Lappe JM, Travers-Gustafson D, Davies KM, Recker RR, Heaney RP. Vitamin D and calcium supplementation reduces cancer risk: results of a randomized trial. The American Journal of Clinical Nutrition 2007; 85:1586-1591

20. Jorde R, Sneve M, Figenschau Y, Svartberg J, Waterloo K. Effects of vitamin D supplementation on symptoms of depression in overweight and obese subjects: randomized double blind trial. Journal of Internal Medicine 2008; 264:599-609

21. Bertone-Johnson ER, Powers SI, Spangler L, Brunner RL, Michael YL, Larson JC, Millen AE, Bueche MN, Salmoirago-Blotcher E, Liu S, Wassertheil-Smoller S, Ockene JK, Ockene I, Manson JE. Vitamin D intake from foods and supplements and depressive symptoms in a diverse population of older women. The American Journal of Clinical Nutrition 2011; 94:1104-1112

22. Pincikova T, Paquin-Proulx D, Sandberg JK, Flodström-Tullberg M, Hjelte L. Clinical impact of vitamin $\mathrm{D}$ treatment in cystic fibrosis: a pilot randomized, controlled trial. European Journal Of Clinical Nutrition 2016; 71:203 
23. Barry EL, Peacock JL, Rees JR, Bostick RM, Robertson DJ, Bresalier RS, Baron JA. Vitamin D Receptor Genotype, Vitamin D(3) Supplementation, and Risk of Colorectal Adenomas: A Randomized Clinical Trial. JAMA oncology 2017; 3:628-635

24. Weaver CM, Alexander DD, Boushey CJ, Dawson-Hughes B, Lappe JM, LeBoff MS, Liu S, Looker AC, Wallace TC, Wang DD. Calcium plus vitamin D supplementation and risk of fractures: an updated meta-analysis from the National Osteoporosis Foundation. Osteoporosis International 2016; 27:367-376

25. Bischoff-Ferrari HA, Willett WC, Wong JB, Giovannucci E, Dietrich T, Dawson-Hughes B. Fracture prevention with vitamin $\mathrm{d}$ supplementation: A meta-analysis of randomized controlled trials. JAMA 2005; 293:2257-2264

26. Manson JE, Cook NR, Lee IM, Christen W, Bassuk SS, Mora S, Gibson H, Gordon D, Copeland T, D’Agostino D, Friedenberg G, Ridge C, Bubes V, Giovannucci EL, Willett WC, Buring JE. Vitamin D Supplements and Prevention of Cancer and Cardiovascular Disease. New England Journal of Medicine 2018;

27. Melamed ML, Manson JE. Vitamin D and cardiovascular disease and cancer: not too much and not too little? The need for clinical trials. Women's health (London, England) 2011; 7:419-424

28. Aloia JF, Patel M, DiMaano R, Li-Ng M, Talwar SA, Mikhail M, Pollack S, Yeh JK. Vitamin D intake to attain a desired serum 25-hydroxyvitamin D concentration. The American Journal of Clinical Nutrition 2008; 87:1952-1958

29. Binkley N, Lappe J, Singh RJ, Khosla S, Krueger D, Drezner MK, Blank RD. Can vitamin D metabolite measurements facilitate a "treat-to-target" paradigm to guide vitamin $D$ supplementation? Osteoporosis international : a journal established as result of cooperation between the European Foundation for Osteoporosis and the National Osteoporosis Foundation of the USA 2015; 26:1655-1660

30. Nimitphong H, Saetung S, Chanprasertyotin S, Chailurkit L-o, Ongphiphadhanakul B. Changes in circulating 25-hydroxyvitamin $\mathrm{D}$ according to vitamin $\mathrm{D}$ binding protein genotypes after vitamin $\mathrm{D} 3$ or D2supplementation. Nutrition Journal 2013; 12:39

31. Engelman CD, Fingerlin TE, Langefeld CD, Hicks PJ, Rich SS, Wagenknecht LE, Bowden DW, Norris JM. Genetic and environmental determinants of 25-hydroxyvitamin D and 1,25dihydroxyvitamin D levels in Hispanic and African Americans. J Clin Endocrinol Metab 2008; 93

32. Engelman CD, Meyers KJ, lyengar SK, Liu Z, Karki CK, Igo RP, Truitt B, Robinson J, Sarto GE, Wallace R, Blodi BA, Klein ML, Tinker L, LeBlanc ES, Jackson RD, Song Y, Manson JE, Mares JA, Millen AE. Vitamin D Intake and Season Modify the Effects of the GC and CYP2R1 Genes on 25-Hydroxyvitamin D Concentrations. The Journal of Nutrition 2013; 143:17-26

33. Wjst M. Linking vitamin D, the microbiome and allergy. Allergy 2017; 72:329-330

34. Ahn J, Yu K, Stolzenberg-Solomon R, Simon KC, McCullough ML, Gallicchio L, Jacobs EJ, Ascherio A, Helzlsouer K, Jacobs KB, Li Q, Weinstein SJ, Purdue M, Virtamo J, Horst R, Wheeler W, Chanock S, Hunter DJ, Hayes RB, Kraft P, Albanes D. Genome-wide association study of circulating vitamin D levels. Human Molecular Genetics 2010; 19:2739-2745

35. Engelman CD, Meyers KJ, Ziegler JT, Taylor KD, Palmer ND, Haffner SM, Fingerlin TE, Wagenknecht LE, Rotter JI, Bowden DW, Langefeld CD, Norris JM. Genome-wide association study of vitamin D concentrations in Hispanic Americans: The IRAS Family Study. The Journal of steroid biochemistry and molecular biology 2010; 122:186-192

36. Jiang X, O'Reilly PF, Aschard H, Hsu Y-H, Richards JB, Dupuis J, Ingelsson E, Karasik D, Pilz S, Berry D, Kestenbaum B, Zheng J, Luan J, Sofianopoulou E, Streeten EA, Albanes D, Lutsey PL, Yao L, Tang W, Econs MJ, Wallaschofski H, Völzke H, Zhou A, Power C, McCarthy MI, Michos ED, Boerwinkle E, Weinstein SJ, Freedman ND, Huang W-Y, Van Schoor NM, van der Velde N, Groot LCPGMd, Enneman A, Cupples LA, Booth SL, Vasan RS, Liu C-T, Zhou Y, Ripatti S, Ohlsson C, Vandenput L, Lorentzon M, Eriksson JG, Shea MK, Houston DK, Kritchevsky SB, Liu Y, Lohman KK, Ferrucci L, Peacock M, Gieger C, Beekman M, Slagboom E, Deelen J, Heemst Dv, Kleber ME, März W, de Boer IH, Wood AC, Rotter JI, Rich SS, Robinson-Cohen C, den Heijer M, Jarvelin M-R, Cavadino A, Joshi PK, Wilson JF, Hayward C, Lind L, Michaëlsson K, Trompet S, Zillikens MC, Uitterlinden AG, Rivadeneira F, Broer L, Zgaga L, Campbell H, Theodoratou E, Farrington SM, Timofeeva M, Dunlop MG, Valdes AM, Tikkanen E, Lehtimäki T, Lyytikäinen L-P, Kähönen M, Raitakari OT, Mikkilä V, Ikram MA, Sattar N, Jukema JW, Wareham NJ, Langenberg C, Forouhi NG, Gundersen TE, Khaw K-T, Butterworth AS, Danesh J, Spector T, 
Wang TJ, Hyppönen E, Kraft P, Kiel DP. Genome-wide association study in 79,366 Europeanancestry individuals informs the genetic architecture of 25-hydroxyvitamin D levels. Nature Communications 2018; 9:260

37. Hong J, Hatchell KE, Bradfield JP, Andrew B, Alessandra C, Chao-Qiang L, Langefeld CD, Lu L, Lu Y, Lutsey PL, Musani SK, Nalls MA, Robinson-Cohen C, Roizen JD, Saxena R, Tucker KL, Ziegler JT, Arking DE, Bis JC, Boerwinkle E, Bottinger EP, Bowden DW, Gilsanz V, Houston DK, Kalkwarf HJ, Kelly A, Lappe JM, Liu Y, Michos ED, Oberfield SE, Palmer ND, Rotter JI, Sapkota B, Shepherd JA, Wilson JG, Basu S, de Boer IH, Divers J, Freedman BI, Grant SFA, Hakanarson H, Harris TB, Kestenbaum BR, Kritchevsky SB, Loos RJF, Norris JM, Norwood AF, Ordovas JM, Pankow JS, Psaty BM, Sanhgera DK, Wagenknecht LE, Zemel BS, Meigs J, Dupuis J, Florez JC, Wang T, Liu C-T, Engelman CD, Billings LK. Trans-ethnic Evaluation Identifies Novel Low Frequency Loci Associated with 25-Hydroxyvitamin D Concentrations. The Journal of Clinical Endocrinology \& Metabolism 2018:jc.2017-01802-jc.02017-01802

38. Manolio TA, Collins FS, Cox NJ, Goldstein DB, Hindorff LA, Hunter DJ, McCarthy MI, Ramos EM, Cardon LR, Chakravarti A. Finding the missing heritability of complex diseases. Nature 2009; 461

39. Mormino EC, Sperling RA, Holmes AJ, Buckner RL, De Jager PL, Smoller JW, Sabuncu MR, Alzheimer's Dis Neuroimaging I. Polygenic risk of Alzheimer disease is associated with early- and late-life processes. Neurology 2016; 87:481-488

40. Desikan RS, Fan CC, Wang Y, Schork AJ, Cabral HJ, Cupples LA, Thompson WK, Besser L, Kukull WA, Holland D, Chen C-H, Brewer JB, Karow DS, Kauppi K, Witoelar A, Karch CM, Bonham LW, Yokoyama JS, Rosen HJ, Miller BL, Dillon WP, Wilson DM, Hess CP, PericakVance M, Haines JL, Farrer LA, Mayeux R, Hardy J, Goate AM, Hyman BT, Schellenberg GD, McEvoy LK, Andreassen OA, Dale AM. Genetic assessment of age-associated Alzheimer disease risk: Development and validation of a polygenic hazard score. PLoS Medicine 2017; $14: \mathrm{e} 1002258$

41. Tang $W$, Schwienbacher $C$, Lopez Lorna M, Ben-Shlomo $Y$, Oudot-Mellakh T, Johnson Andrew D, Samani Nilesh J, Basu S, Gögele M, Davies G, Lowe Gordon D, Tregouet D-A, Tan A, Pankow James S, Tenesa A, Levy D, Volpato Claudia B, Rumley A, Gow Alan J, Minelli C, Yarnell John W, Porteous David J, Starr John M, Gallacher J, Boerwinkle E, Visscher Peter M, Pramstaller Peter P, Cushman M, Emilsson V, Plump Andrew S, Matijevic N, Morange P-E, Deary lan J, Hicks Andrew A, Folsom Aaron R. Genetic Associations for Activated Partial Thromboplastin Time and Prothrombin Time, their Gene Expression Profiles, and Risk of Coronary Artery Disease. American Journal of Human Genetics 2012; 91:152-162

42. Dudbridge F. Power and Predictive Accuracy of Polygenic Risk Scores. PLOS Genetics 2013; 9:e1003348

43. Euesden J, Lewis CM, O'Reilly PF. PRSice: Polygenic Risk Score software. Bioinformatics 2015; 31:1466-1468

44. Nissen J, Rasmussen LB, Ravn-Haren G, Andersen EW, Hansen B, Andersen R, Mejborn H, Madsen KH, Vogel U. Common Variants in CYP2R1 and GC Genes Predict Vitamin D Concentrations in Healthy Danish Children and Adults. PLOS ONE 2014; 9:e89907

45. Shao B, Jiang S, Muyiduli X, Wang S, Mo M, Li M, Wang Z, Yu Y. Vitamin D pathway gene polymorphisms influenced vitamin $D$ level among pregnant women. Clinical Nutrition

46. Zhang Z, He J-W, Fu W-Z, Zhang C-Q, Zhang Z-L. An analysis of the association between the vitamin $D$ pathway and serum 25-hydroxyvitamin $D$ levels in a healthy Chinese population. Journal of Bone and Mineral Research 2013; 28:1784-1792

47. Chandler PD, Tobias DK, Wang L, Smith-Warner SA, Chasman DI, Rose L, Giovannucci EL, Buring JE, Ridker PM, Cook NR, Manson JE, Sesso HD. Association between Vitamin D Genetic Risk Score and Cancer Risk in a Large Cohort of U.S. Women. Nutrients 2018; 10:55

48. Mazahery $\mathrm{H}$, von Hurst PR. Factors Affecting 25-Hydroxyvitamin D Concentration in Response to Vitamin D Supplementation. Nutrients 2015; 7:5111-5142

49. Didriksen A, Grimnes G, Hutchinson M, Kjærgaard M, Svartberg J, Joakimsen R, Jorde R. The serum 25-hydroxyvitamin $D$ response to vitamin $D$ supplementation is related to genetic factors, BMI, and Baseline levels. Vol 169.

50. INVESTIGATORS TA. THE ATHEROSCLEROSIS RISK IN COMMUNIT (ARIC) STUI)Y: DESIGN AND OBJECTWES. American Journal of Epidemiology 1989; 129:687-702 
51. Anderson GL, Manson J, Wallace R, Lund B, Hall D, Davis S, Shumaker S, Wang C-Y, Stein E, Prentice RL. Implementation of the women's health initiative study design. Annals of Epidemiology 2003; 13:S5-S17

52. Kwak SK, Kim JH. Statistical data preparation: management of missing values and outliers. Korean Journal of Anesthesiology 2017; 70:407-411

53. Cornelis MC, Agrawal A, Cole JW, Hansel NN, Barnes KC, Beaty TH, Bennett SN, Bierut LJ, Boerwinkle E, Doheny KF, Feenstra B, Feingold E, Fornage M, Haiman CA, Harris EL, Hayes MG, Heit JA, Hu FB, Kang JH, Laurie CC, Ling H, Manolio TA, Marazita ML, Mathias RA, Mirel DB, Paschall J, Pasquale LR, Pugh EW, Rice JP, Udren J, van Dam RM, Wang X, Wiggs JL, Williams K, Yu K. The Gene, Environment Association Studies Consortium (GENEVA): Maximizing the Knowledge Obtained from GWAS by Collaboration Across Studies of Multiple Conditions. Genetic epidemiology 2010; 34:364-372

54. Musunuru K, Lettre G, Young T, Farlow DN, Pirruccello JP, Ejebe KG, Keating BJ, Yang Q, Chen M-H, Lapchyk N, Crenshaw A, Ziaugra L, Rachupka A, Benjamin EJ, Cupples LA, Fornage M, Fox ER, Heckbert SR, Hirschhorn JN, Newton-Cheh CH, Nizzari MM, Paltoo DN, Papanicolaou GJ, Patel SR, Psaty BM, Rader DJ, Redline S, Rich SS, Rotter JI, Taylor HA, Tracy RP, Vasan RS, Wilson JG, Kathiresan S, Fabsitz RR, Boerwinkle E, Gabriel SB. Candidate Gene Association Resource (CARe): Design, Methods, and Proof of Concept. Circulation Cardiovascular genetics 2010; 3:267-275

55. Manichaikul A, Palmas W, Rodriguez CJ, Peralta CA, Divers J, Guo X, Chen W-M, Wong Q, Williams K, Kerr KF, Taylor KD, Tsai MY, Goodarzi MO, Sale MM, Diez-Roux AV, Rich SS, Rotter JI, Mychaleckyj JC. Population Structure of Hispanics in the United States: The Multi-Ethnic Study of Atherosclerosis. PLoS Genetics 2012; 8:e1002640

56. Matise TC, Ambite JL, Buyske S, Carlson CS, Cole SA, Crawford DC, Haiman CA, Heiss G, Kooperberg C, Marchand LL, Manolio TA, North KE, Peters U, Ritchie MD, Hindorff LA, Haines $\mathrm{JL}$. The Next PAGE in Understanding Complex Traits: Design for the Analysis of Population Architecture Using Genetics and Epidemiology (PAGE) Study. American Journal of Epidemiology $2011 ; 174: 849-859$

57. Anderson G. WHI Harmonized and Imputed GWAS Data dbGaP Study Accession: phs000746.v2.p3. Accessed April 3, 2018.

58. Das S, Forer L, Schonherr S, Sidore C, Locke AE, Kwong A, Vrieze SI, Chew EY, Levy S, McGue M, Schlessinger D, Stambolian D, Loh P-R, lacono WG, Swaroop A, Scott LJ, Cucca F, Kronenberg F, Boehnke M, Abecasis GR, Fuchsberger C. Next-generation genotype imputation service and methods. Nat Genet 2016; 48:1284-1287

59. Loh P-R, Danecek P, Palamara PF, Fuchsberger C, Reshef YA, Finucane HK, Schoenherr S, Forer L, McCarthy S, Abecasis GR, Durbin R, Price AL. Reference-based phasing using the Haplotype Reference Consortium panel. Nature genetics 2016; 48:1443-1448

60. Johnston HR, Hu Y-J, Gao J, O'Connor TD, Abecasis GR, Wojcik GL, Gignoux CR, Gourraud PA, Lizee A, Hansen M, Genuario R, Bullis D, Lawley C, Kenny EE, Bustamante C, Beaty TH, Mathias RA, Barnes KC, Qin ZS, Consortium C. Identifying tagging SNPs for African specific genetic variation from the African Diaspora Genome. Scientific Reports 2017; 7:46398

61. Danecek P, Auton A, Abecasis G, Albers CA, Banks E, DePristo MA, Handsaker RE, Lunter G, Marth GT, Sherry ST, McVean G, Durbin R. The variant call format and VCFtools. Bioinformatics $2011 ; 27: 2156-2158$

62. Purcell S, Neale B, Todd-Brown K, Thomas L, Ferreira MAR, Bender D, Maller J, Sklar P, de Bakker PIW, Daly MJ, Sham PC. PLINK: a tool set for whole-genome association and populationbased linkage analyses. American journal of human genetics 2007; 81:559-575

63. The Genomes Project C, McVean GA, Altshuler DM, Durbin RM, Abecasis GR, Bentley DR, Chakravarti A, Clark AG, Donnelly P, Eichler EE, Flicek P, Gabriel SB, Gibbs RA, Green ED, Hurles ME, Knoppers BM, Korbel JO, Lander ES, Lee C, Lehrach H, Mardis ER, Marth GT, McVean GA, Nickerson DA, Schmidt JP, Sherry ST, Wang J, Wilson RK, Gibbs RA, Dinh H, Kovar C, Lee S, Lewis L, Muzny D, Reid J, Wang M, Wang J, Fang X, Guo X, Jian M, Jiang H, Jin X, Li G, Li J, Li Y, Li Z, Liu X, Lu Y, Ma X, Su Z, Tai S, Tang M, Wang B, Wang G, Wu H, Wu R, Yin Y, Zhang W, Zhao J, Zhao M, Zheng X, Zhou Y, Lander ES, Altshuler DM, Gabriel SB, Gupta N, Flicek P, Clarke L, Leinonen R, Smith RE, Zheng-Bradley X, Bentley DR, Grocock R, Humphray S, James T, Kingsbury Z, Lehrach H, Sudbrak R, Albrecht MW, Amstislavskiy VS, 
Borodina TA, Lienhard M, Mertes F, Sultan M, Timmermann B, Yaspo M-L, Sherry ST, McVean GA, Mardis ER, Wilson RK, Fulton L, Fulton R, Weinstock GM, Durbin RM, Balasubramaniam S, Burton J, Danecek P, Keane TM, Kolb-Kokocinski A, McCarthy S, Stalker J, Quail M, Schmidt JP, Davies CJ, Gollub J, Webster T, Wong B, Zhan Y, Auton A, Gibbs RA, Yu F, Bainbridge M, Challis D, Evani US, Lu J, Muzny D, Nagaswamy U, Reid J, Sabo A, Wang Y, Yu J, Wang J, Coin LJM, Fang L, Guo X, Jin X, Li G, Li Q, Li Y, Li Z, Lin H, Liu B, Luo R, Qin N, Shao H, Wang B, Xie Y, Ye C, Yu C, Zhang F, Zheng H, Zhu H, Marth GT, Garrison EP, Kural D, Lee W-P, Fung Leong W, Ward AN, Wu J, Zhang M, Lee C, Griffin L, Hsieh C-H, Mills RE, Shi X, von Grotthuss M, Zhang C, Daly MJ, DePristo MA, Altshuler DM, Banks E, Bhatia G, Carneiro MO, del Angel G, Gabriel SB, Genovese G, Gupta N, Handsaker RE, Hartl C, Lander ES, McCarroll SA, Nemesh JC, Poplin RE, Schaffner SF, Shakir K, Yoon SC, Lihm J, Makarov V, Jin H, Kim W, Cheol Kim K, Korbel JO, Rausch T, Flicek P, Beal K, Clarke L, Cunningham F, Herrero J, McLaren WM, Ritchie GRS, Smith RE, Zheng-Bradley X, Clark AG, Gottipati S, Keinan A, Rodriguez-Flores JL, Sabeti PC, Grossman SR, Tabrizi S, Tariyal R, Cooper DN, Ball EV, Stenson PD, Bentley DR, Barnes B, Bauer M, Keira Cheetham R, Cox T, Eberle M, Humphray S, Kahn S, Murray L, Peden J, Shaw R, Ye K, Batzer MA, Konkel MK, Walker JA, MacArthur DG, Lek M, Sudbrak, Amstislavskiy VS, Herwig R, Shriver MD, Bustamante CD, Byrnes JK, De La Vega FM, Gravel S, Kenny EE, Kidd JM, Lacroute P, Maples BK, Moreno-Estrada A, Zakharia F, Halperin E, Baran Y, Craig DW, Christoforides A, Homer N, Izatt T, Kurdoglu AA, Sinari SA, Squire K, Sherry ST, Xiao C, Sebat J, Bafna V, Ye K, Burchard EG, Hernandez RD, Gignoux CR, Haussler D, Katzman SJ, James Kent W, Howie B, Ruiz-Linares A, Dermitzakis ET, Lappalainen T, Devine SE, Liu X, Maroo A, Tallon LJ, Rosenfeld JA, Michelson LP, Abecasis GR, Min Kang H, Anderson P, Angius A, Bigham A, Blackwell T, Busonero F, Cucca F, Fuchsberger C, Jones C, Jun G, Li Y, Lyons R, Maschio A, Porcu E, Reinier F, Sanna S, Schlessinger D, Sidore C, Tan A, Kate Trost M, Awadalla P, Hodgkinson A, Lunter G, McVean GA, Marchini JL, Myers S, Churchhouse C, Delaneau O, Gupta-Hinch A, Iqbal Z, Mathieson I, Rimmer A, Xifara DK, Oleksyk TK, Fu Y, Liu X, Xiong M, Jorde L, Witherspoon D, Xing J, Eichler EE, Browning BL, Alkan C, Hajirasouliha I, Hormozdiari F, Ko A, Sudmant PH, Mardis ER, Chen K, Chinwalla A, Ding L, Dooling D, Koboldt DC, McLellan MD, Wallis JW, Wendl MC, Zhang Q, Durbin RM, Hurles ME, Tyler-Smith C, Albers CA, Ayub Q, Balasubramaniam S, Chen Y, Coffey AJ, Colonna V, Danecek P, Huang N, Jostins L, Keane TM, Li H, McCarthy S, Scally A, Stalker J, Walter K, Xue Y, Zhang Y, Gerstein MB, Abyzov A, Balasubramanian S, Chen J, Clarke D, Fu Y, Habegger L, Harmanci AO, Jin M, Khurana E, Jasmine Mu X, Sisu C, Li Y, Luo R, Zhu H, Lee C, Griffin L, Hsieh C-H, Mills RE, Shi X, von Grotthuss M, Zhang C, Marth GT, Garrison EP, Kural D, Lee W-P, Ward AN, Wu J, Zhang M, McCarroll SA, Altshuler DM, Banks E, del Angel G, Genovese G, Handsaker RE, Hartl C, Nemesh JC, Shakir K, Yoon SC, Linm J, Makarov V, Degenhardt J, Flicek P, Clarke L, Smith RE, Zheng-Bradley X, Korbel JO, Rausch T, Stütz AM, Bentley DR, Barnes B, Keira Cheetham R, Eberle M, Humphray S, Kahn S, Murray L, Shaw R, Ye K, Batzer MA, Konkel MK, Walker JA, Lacroute P, Craig DW, Homer N, Church D, Xiao C, Sebat J, Bafna V, Michaelson JJ, Ye K, Devine SE, Liu X, Maroo A, Tallon LJ, Lunter G, McVean GA, lqbal Z, Witherspoon D, Xing J, Eichler EE, Alkan C, Hajirasouliha I, Hormozdiari F, Ko A, Sudmant PH, Chen K, Chinwalla A, Ding L, McLellan MD, Wallis JW, Hurles ME, Blackburne B, Li H, Lindsay SJ, Ning Z, Scally A, Walter K, Zhang Y, Gerstein MB, Abyzov A, Chen J, Clarke D, Khurana E, Jasmine Mu X, Sisu C, Gibbs RA, Yu F, Bainbridge M, Challis D, Evani US, Kovar C, Lewis L, Lu J, Muzny D, Nagaswamy U, Reid J, Sabo A, Yu J, Guo X, Li Y, Wu R, Marth GT, Garrison EP, Fung Leong W, Ward AN, del Angel G, DePristo MA, Gabriel SB, Gupta N, Hartl C, Poplin RE, Clark AG, Rodriguez-Flores JL, Flicek P, Clarke L, Smith RE, Zheng-Bradley X, MacArthur DG, Bustamante CD, Gravel S, Craig DW, Christoforides A, Homer N, Izatt T, Sherry ST, Xiao C, Dermitzakis ET, Abecasis GR, Min Kang H, McVean GA, Mardis ER, Dooling D, Fulton L, Fulton R, Koboldt DC, Durbin RM, Balasubramaniam S, Keane TM, McCarthy S, Stalker J, Gerstein MB, Balasubramanian S, Habegger L, Garrison EP, Gibbs RA, Bainbridge M, Muzny D, Yu F, Yu J, del Angel G, Handsaker RE, Makarov V, Rodriguez-Flores JL, Jin H, Kim W, Cheol Kim K, Flicek $P$, Beal K, Clarke L, Cunningham F, Herrero J, McLaren WM, Ritchie GRS, Zheng-Bradley X, Tabrizi S, MacArthur DG, Lek M, Bustamante CD, De La Vega FM, Craig DW, Kurdoglu AA, Lappalainen T, Rosenfeld JA, Michelson LP, Awadalla P, Hodgkinson A, McVean GA, Chen K, Tyler-Smith C, Chen Y, Colonna V, Frankish A, Harrow J, Xue Y, Gerstein MB, Abyzov A, 
905

906

Balasubramanian S, Chen J, Clarke D, Fu Y, Harmanci AO, Jin M, Khurana E, Jasmine Mu X, Sisu C, Gibbs RA, Fowler G, Hale W, Kalra D, Kovar C, Muzny D, Reid J, Wang J, Guo X, Li G, Li Y, Zheng X, Altshuler DM, Flicek P, Clarke L, Barker J, Kelman G, Kulesha E, Leinonen R, McLaren WM, Radhakrishnan R, Roa A, Smirnov D, Smith RE, Streeter I, Toneva I, Vaughan B, Zheng-Bradley X, Bentley DR, Cox T, Humphray S, Kahn S, Sudbrak R, Albrecht MW, Lienhard M, Craig DW, Izatt T, Kurdoglu AA, Sherry ST, Ananiev V, Belaia Z, Beloslyudtsev D, Bouk N, Chen C, Church D, Cohen R, Cook C, Garner J, Hefferon T, Kimelman M, Liu C, Lopez J, Meric P, O'Sullivan C, Ostapchuk Y, Phan L, Ponomarov S, Schneider V, Shekhtman E, Sirotkin K, Slotta D, Xiao C, Zhang H, Haussler D, Abecasis GR, McVean GA, Alkan C, Ko A, Dooling D, Durbin RM, Balasubramaniam S, Keane TM, McCarthy S, Stalker J, Chakravarti A, Knoppers BM, Abecasis GR, Barnes KC, Beiswanger C, Burchard EG, Bustamante CD, Cai H, Cao H, Durbin RM, Gharani N, Gibbs RA, Gignoux CR, Gravel S, Henn B, Jones D, Jorde L, Kaye JS, Keinan A, Kent A, Kerasidou A, Li Y, Mathias R, McVean GA, Moreno-Estrada A, Ossorio PN, Parker M, Reich D, Rotimi CN, Royal CD, Sandoval K, Su Y, Sudbrak R, Tian Z, Timmermann B, Tishkoff S, Toji LH, Tyler-Smith C, Via M, Wang Y, Yang H, Yang L, Zhu J, Bodmer W, Bedoya G, Ruiz-Linares A, Zhi Ming C, Yang G, Jia You C, Peltonen L, Garcia-Montero A, Orfao A, Dutil J, Martinez-Cruzado JC, Oleksyk TK, Brooks LD, Felsenfeld AL, McEwen JE, Clemm NC, Duncanson A, Dunn M, Green ED, Guyer MS, Peterson JL, Abecasis GR, Auton A, Brooks LD, DePristo MA, Durbin RM, Handsaker RE, Min Kang H, Marth GT, McVean GA. An integrated map of genetic variation from 1,092 human genomes. Nature 2012; 491:56

64. McKibben RA, Zhao D, Lutsey PL, Schneider ALC, Guallar E, Mosley TH, Michos ED. Factors Associated With Change in 25-Hydroxyvitamin D Levels Over Longitudinal Follow-Up in the ARIC Study. The Journal of clinical endocrinology and metabolism 2016; 101:33-43

65. Robinson-Cohen $\mathrm{C}$, Hoofnagle AN, Ix JH, et al. Racial differences in the association of serum 25hydroxyvitamin d concentration with coronary heart disease events. JAMA 2013; 310:179-188

66. Zhu Z, Zhang F, Hu H, Bakshi A, Robinson MR, Powell JE, Montgomery GW, Goddard ME, Wray NR, Visscher PM, Yang J. Integration of summary data from GWAS and eQTL studies predicts complex trait gene targets. Nature Genetics 2016; 48:481

67. Ware EB, Schmitz LL, Faul JD, Gard A, Mitchell C, Smith JA, Zhao W, Weir D, Kardia SL. Heterogeneity in polygenic scores for common human traits. bioRxiv 2017:106062

68. Yang J, Lee SH, Goddard ME, Visscher PM. GCTA: A Tool for Genome-wide Complex Trait Analysis. American Journal of Human Genetics 2011; 88:76-82

69. Johnson AD, Handsaker RE, Pulit SL, Nizzari MM, O'Donnell CJ, de Bakker PIW. SNAP: a webbased tool for identification and annotation of proxy SNPs using HapMap. Bioinformatics 2008; 24:2938-2939

70. Coram MA, Fang H, Candille SI, Assimes TL, Tang H. Leveraging Multi-ethnic Evidence for Risk Assessment of Quantitative Traits in Minority Populations. American Journal of Human Genetics 2017; 101:218-226

71. Vassos E, Di Forti M, Coleman J, lyegbe C, Prata D, Euesden J, O'Reilly P, Curtis C, Kolliakou A, Patel H, Newhouse S, Traylor M, Ajnakina O, Mondelli V, Marques TR, Gardner-Sood P, Aitchison KJ, Powell J, Atakan Z, Greenwood KE, Smith S, Ismail K, Pariante C, Gaughran F, Dazzan P, Markus HS, David AS, Lewis CM, Murray RM, Breen G. An Examination of Polygenic Score Risk Prediction in Individuals With First-Episode Psychosis. Biological Psychiatry 2017; 81:470-477

72. Márquez-Luna C, Loh P-R, Price AL. Multiethnic polygenic risk scores improve risk prediction in diverse populations. Genetic Epidemiology 2017; 41:811-823

73. Cranney A, Horsley T, O'Donnell S, Weiler H, Puil L, Ooi D, Atkinson S, Ward L, Moher D, Hanley D, Fang M, Yazdi F, Garritty C, Sampson M, Barrowman N, Tsertsvadze A, Mamaladze V. Effectiveness and safety of vitamin $D$ in relation to bone health. Evidence Report/Technology Assessment 2007:1-235

74. Haskins J. Wanted: 1 million people to help transform precision medicine: All of Us program open for enrollment. The Nation's Health 2018; 48:1-16

75. Mak T, Porsch RM, Choi SW, Sham PC. Polygenic scores for UK Biobank scale data. bioRxiv 2018; 
Figure 1. The polygenic score (PGS) performance in those of European or African ancestry. The $x$ axis displays selected $p$-value thresholds for single nucleotide polymorphisms (SNPs) included in the PGS. The $y$-axis displays the proportion of phenotypic variance captured by the PGS. Yellow bars correspond to a strong association (more significant $p$-value) between the PGS and $\log (25(\mathrm{OH}) \mathrm{D}$ than do blue bars. In panel A, the most optimally performing PGS has the tallest bar ( $p$-value threshold $=0.00035$ ) and captures $1.4 \%$ of the variance in $\log [25(\mathrm{OH}) \mathrm{D}]$. In panel $B$, the most optimally performing PGS has the tallest bar $(p$-value threshold $=0.01265$ ) and captures $2.9 \%$ of the variance in $\log [25(\mathrm{OH}) \mathrm{D}]$.

Figure 2. Visual representation of the association between polygenic score (PGS) decile and normalized vitamin D concentrations in those of European ancestry. The $x$-axis is the PGS decile, where lower decile means more risk of low vitamin $D$ concentrations The $y$-axis is vitamin $D$ concentrations (normalized for comparison between cohorts). Panel A is a plot for the subset of ARIC samples used to discern the optimal p-value threshold for the PGS $(n=1000)$; panel $B$ is a plot for the remaining independent samples $(n=8,569)$. While the exact trend varies by plot, the general trend is that when the PGS decreases (i.e. higher genetic risk) 25(OH)D concentrations decrease. In panel A, moving from the lowest risk to the highest risk decile decreases vitamin D concentrations by $4.0 \mathrm{ng} / \mathrm{ml}$. In panel B, moving from the lowest risk to the highest risk decile decreases vitamin $D$ concentrations by $3.0 \mathrm{ng} / \mathrm{ml}$.

Figure 3. Visual representation of the association between polygenic score (PGS) decile and normalized vitamin $D$ concentrations in those of African ancestry $(n=1,099)$. The $x$-axis is the PGS decile, where lower decile means more risk of low vitamin $D$ concentration. The $y$-axis is vitamin $D$ concentrations (normalized for comparison between cohorts). The trend is that when the PGS decreases (i.e. higher genetic risk) $25(\mathrm{OH}) \mathrm{D}$ concentrations decrease. Moving from the lowest risk to the highest risk quintile decreases vitamin $D$ concentrations by $2.8 \mathrm{ng} / \mathrm{ml}(p=0.0463)$.

Figure 4. Overall single nucleotide polymorphism (SNP) heritability, polygenic score (PGS) SNP heritability and replicated genome-wide assocation study (GWAS) SNP heritability in those of previous replicated GWAS findings, albeit leaving much of the heritability unexplained. 

aCC-BY-ND 4.0 International license.

Figure 1: The PGS performance in those of European (A) or African (B) ancestry

(A)

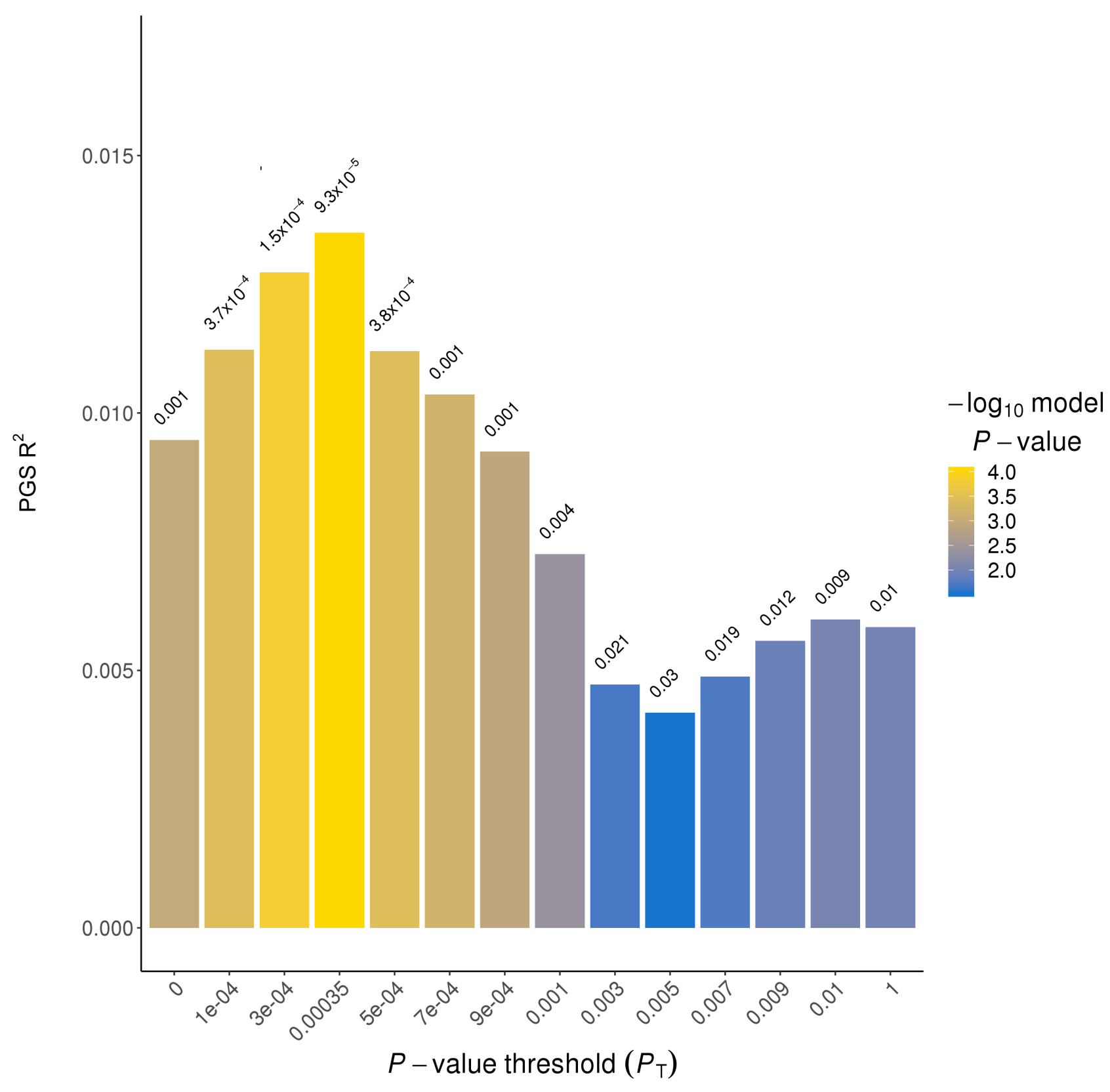


(B)

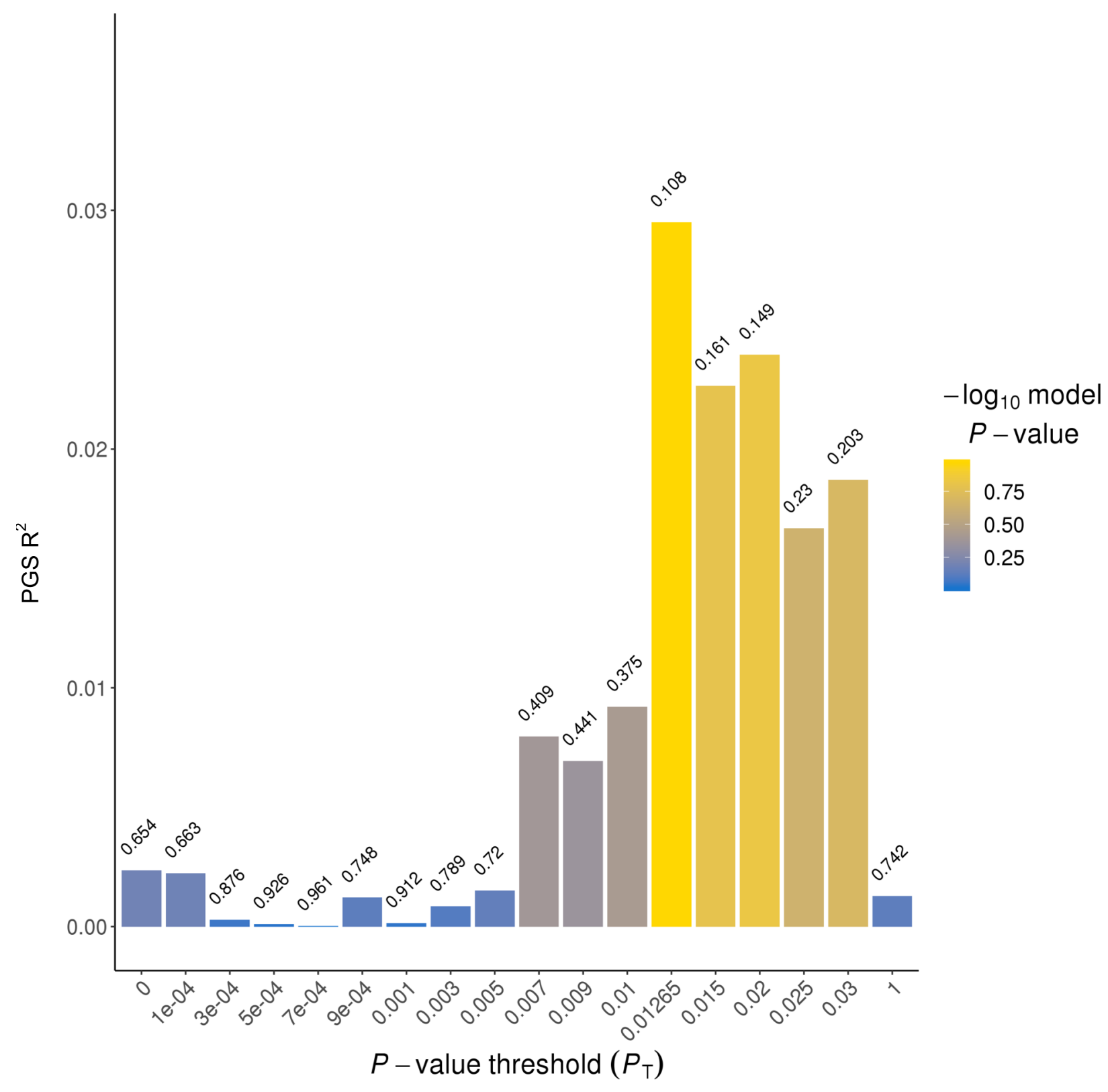


Figure 2: Visual representation of the association between PGS decile and normalized vitamin D concentrations in those of European ancestry $(n=8,569)$

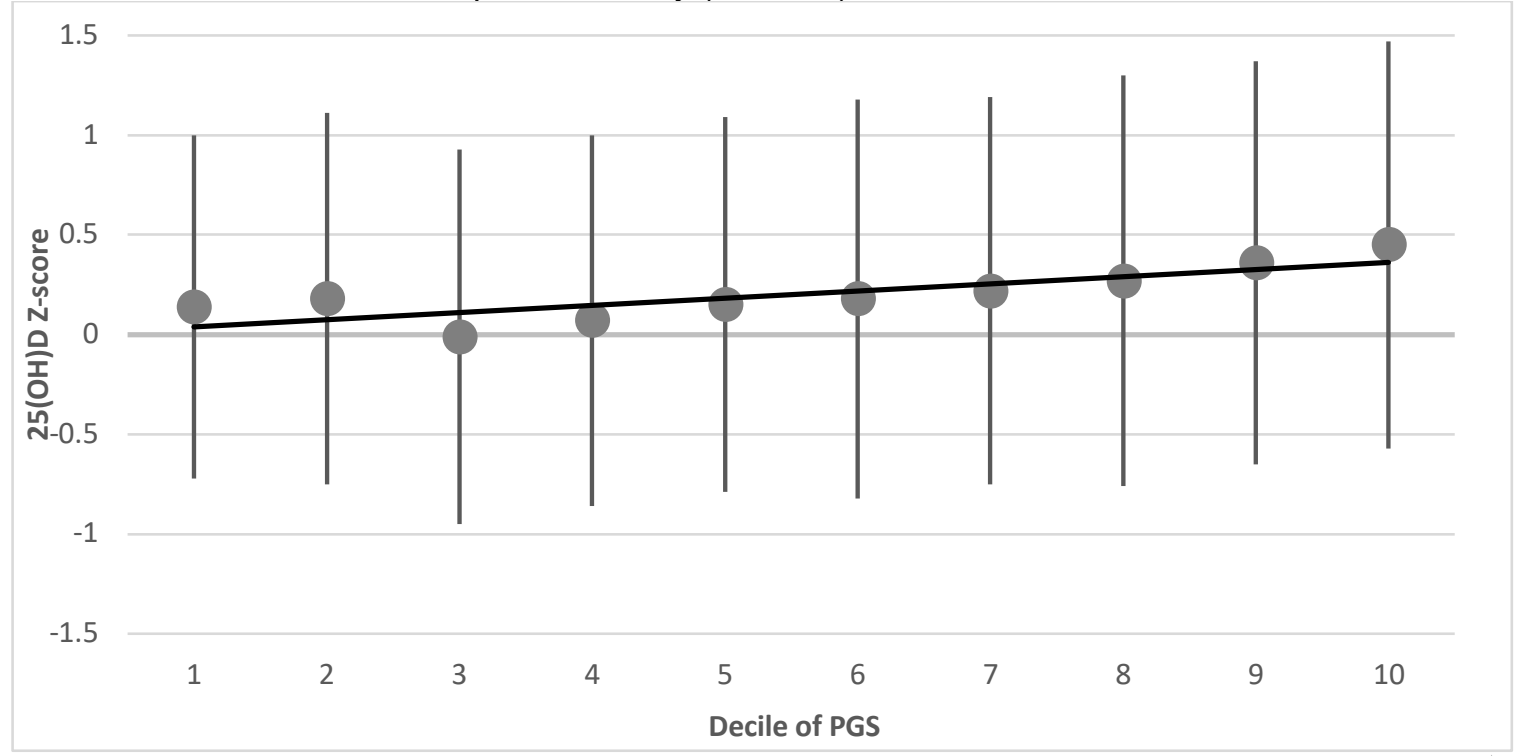


bioRxiv preprint doi: https://doi.org/10.1101/596619; this version posted April 4, 2019. The copyright holder for this preprint (which was not certified by peer review) is the author/funder, who has granted bioRxiv a license to display the preprint in perpetuity. It is made available under aCC-BY-ND 4.0 International license.

Figure 3: Visual representation of the association between PGS decile and normalized vitamin $D$ concentrations in those of African ancestry $(n=1,099)$

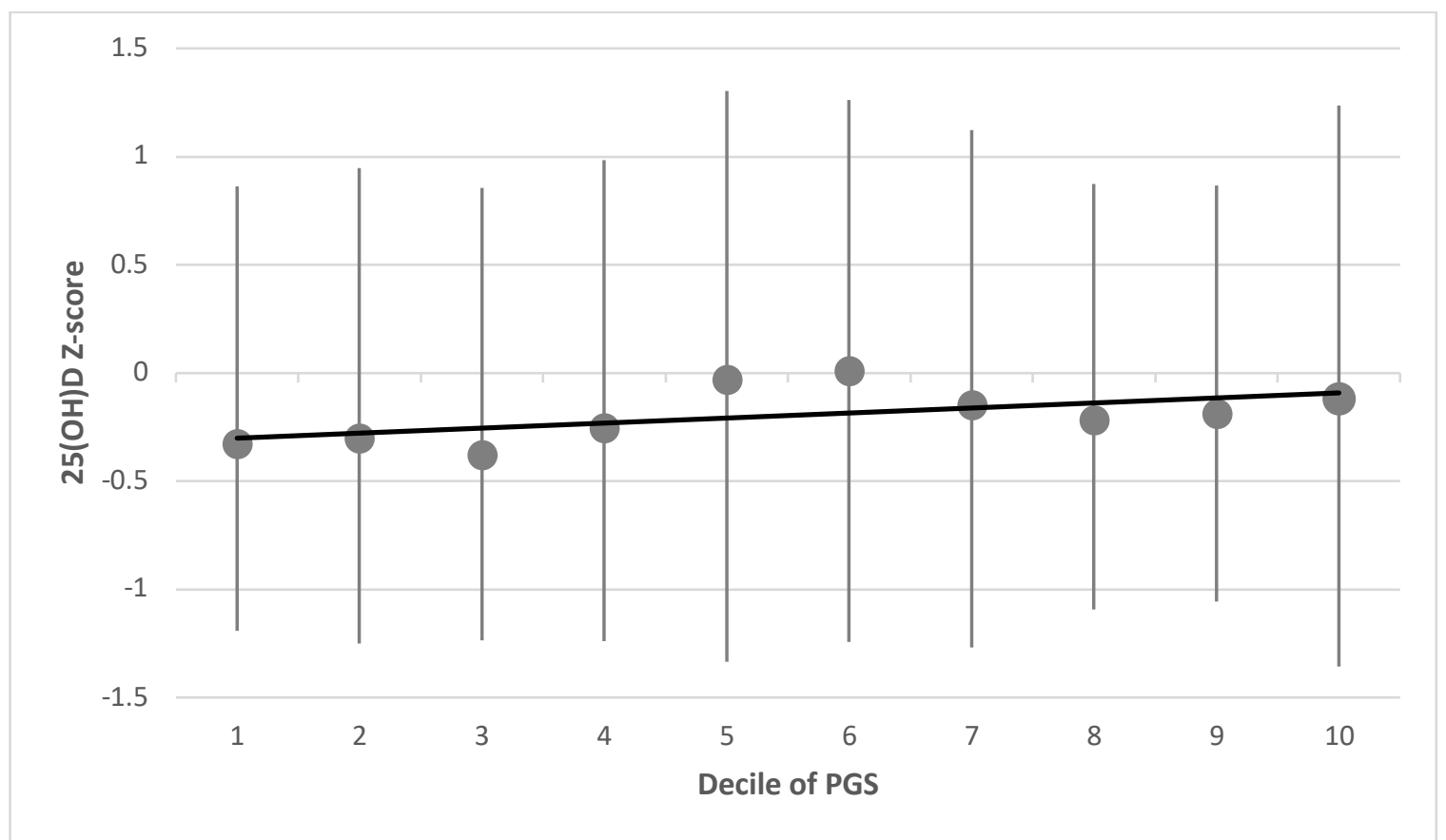



aCC-BY-ND 4.0 International license.

Figure 4: Overall SNP heritability, PGS SNP heritability and replicated GWAS SNP heritability in those of European ancestry

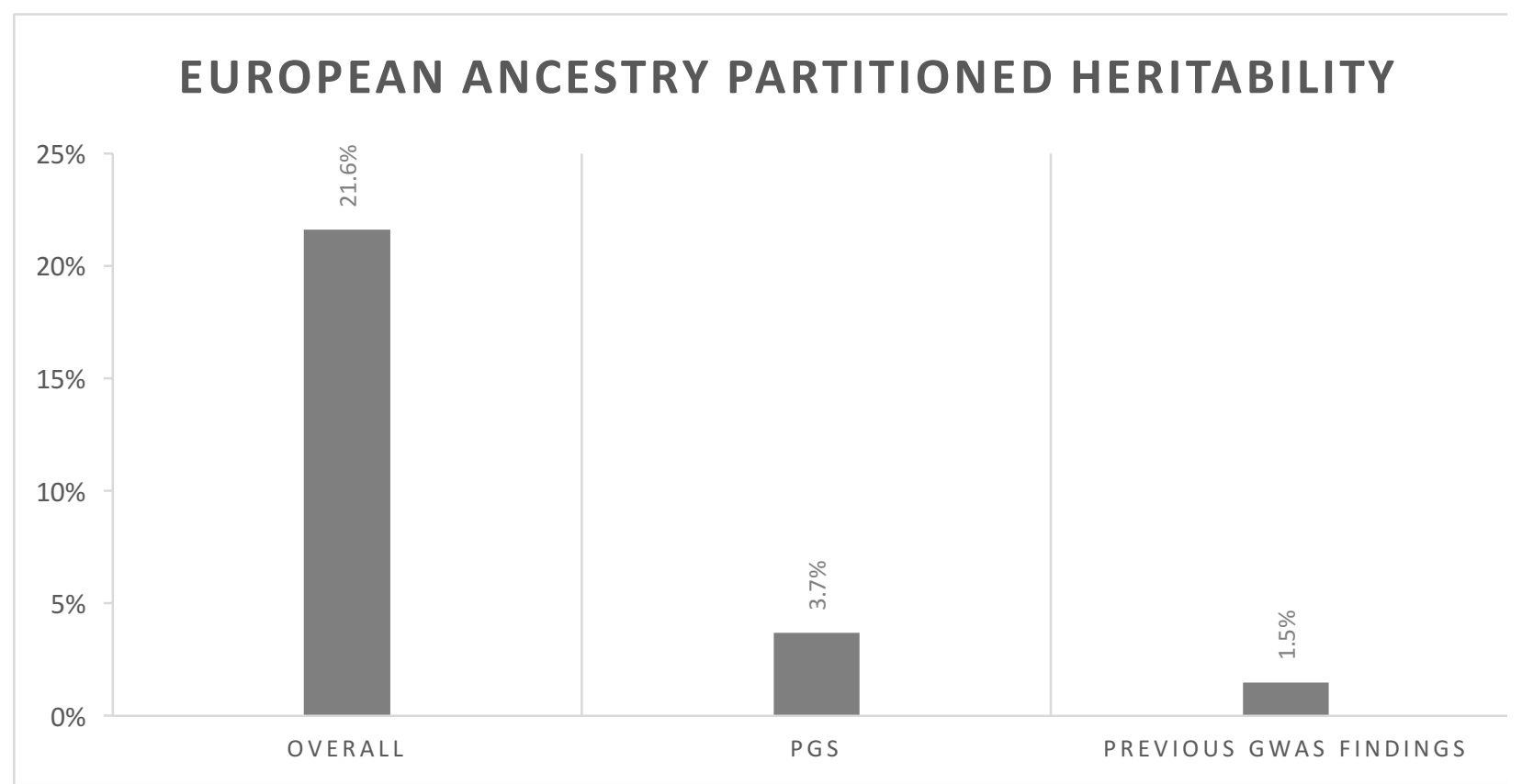


Table 1: Previous GWAS SNPs

\begin{tabular}{|c|c|c|c|c|c|}
\hline SNP ID & Chromosome & Position ${ }^{\mathrm{e}}$ & Gene & $\begin{array}{l}\text { EU LD } \\
\text { block size }\end{array}$ & $\begin{array}{l}\text { AFA LD } \\
\text { block size }\end{array}$ \\
\hline rs2282679 & 4 & 72608383 & $G C$ & $1200 \mathrm{~kb}$ & $2 \mathrm{~kb}$ \\
\hline rs79666294 & 5 & 155047146 & KIF4B & $N A^{c}$ & $200 \mathrm{~kb}$ \\
\hline rs10741657 & 11 & 14893332 & CYP2R1 & $480 \mathrm{~kb}$ & $300 \mathrm{~kb}$ \\
\hline rs12785878 & 11 & 71456403 & NADSYN1/DHCR7 & $120 \mathrm{~kb}$ & $84 \mathrm{~kb}$ \\
\hline rs719700 & 12 & 45635426 & ANO6/ARID2 & $N A^{c}$ & $2 \mathrm{~kb}$ \\
\hline rs10745742 & 12 & 95964751 & $A M D H D 1$ & $50 \mathrm{~kb}$ & $N A^{d}$ \\
\hline rs1410656 & 13 & 46968386 & HTR2A & $N A^{c}$ & $28 \mathrm{~kb}$ \\
\hline rs8018720 & 14 & 39086981 & SEC23A & $180 \mathrm{~kb}$ & $N A^{d}$ \\
\hline rs6013897 & 20 & 54125940 & CYP24A1 & $10 \mathrm{~kb}$ & $4 \mathrm{~kb}$ \\
\hline
\end{tabular}

Abbreviations: SNP, single nucleotide polymorphism; EU, European-ancestry; AFA, African-ancestry; LD, linkage disequilibrium

${ }^{a}$ not in ARIC African-ancestry imputed data; using the RAGGR tool by USC, SNP rs17570361 was found to be a good proxy $\left(r^{2} 0.94\right)$

${ }^{\mathrm{b}}$ not in ARIC African-ancestry imputed data; no proxy for rs6013897, so SNPs within $2 \mathrm{~kb}$ of its position (52742479) were removed

${ }^{\mathrm{C}}$ Novel African ancestry SNP

${ }^{\mathrm{d}}$ Novel European ancestry SNP

e Build 37 
Table 2. Sample characteristics

\begin{tabular}{|c|c|c|c|}
\hline Sample & Metric & European-ancestry set & African-ancestry set \\
\hline \multirow{7}{*}{$\begin{array}{c}\text { PGS } \\
\text { development } \\
\text { sample (from } \\
\text { ARIC) }\end{array}$} & Sample Size & 1,000 & 57 \\
\hline & $\%$ Female & $53.2 \%$ & $49.1 \%$ \\
\hline & Mean Age (SD) [years] & $57.1(5.7)$ & $55.6(6.2)$ \\
\hline & Mean BMI (SD) $\left[\mathrm{kg} / \mathrm{m}^{2}\right]$ & $27.3(4.8)$ & $28.6(5.7)$ \\
\hline & $\begin{array}{l}\text { Mean Available UV radiation } \\
\text { (SD) [units] }\end{array}$ & $5.0(2.5)$ & $7.1(2.4)$ \\
\hline & Mean Vitamin D Intake (SD) [IU] & $219.2(135.2)$ & $221.2(137.3)$ \\
\hline & Mean 25(OH)D (SD) [ng/ml] & $25.7(8.7)$ & $20.9(7.8)$ \\
\hline \multirow{7}{*}{$\begin{array}{c}\text { PGS } \\
\text { validation } \\
\text { sample (from } \\
\text { ARIC, MESA } \\
\text { and WHI) }\end{array}$} & Sample Size & 8,569 & 1,042 \\
\hline & $\%$ Female & $56.1 \%$ & $84 \%^{\mathrm{b}}$ \\
\hline & Mean Age (SD) [years[ & $58.9(7.7)$ & $62.0(8.5)$ \\
\hline & Mean BMI (SD) $\left[\mathrm{kg} / \mathrm{m}^{2}\right]$ & $27.5(5.0)$ & $30.8(6.3)$ \\
\hline & $\begin{array}{l}\text { Mean Available UV radiation } \\
\text { (SD) [units] }\end{array}$ & $4.9(2.5)$ & $5.4(2.5)$ \\
\hline & Mean Vitamin D Intake (SD) [IU] & $172.3(157.0)$ & $99.7(126.1)$ \\
\hline & Mean 25(OH)D (SD) [ng/ml] & $26.5(9.7)$ & $19.2(13.6)$ \\
\hline \multirow{7}{*}{$\begin{array}{c}\text { Heritability } \\
\text { estimation } \\
\text { sample (from } \\
\text { ARIC) }\end{array}$} & Sample Size & 7,119 & 1,719 \\
\hline & $\%$ Female & $53.6 \%$ & $63.5 \%$ \\
\hline & Mean Age (SD) [years[ & $57.1(5.7)$ & $56.4(5.8)$ \\
\hline & Mean BMI (SD) $\left[\mathrm{kg} / \mathrm{m}^{2}\right]$ & $27.3(4.8)$ & $30.2(6.2)$ \\
\hline & $\begin{array}{l}\text { Mean Available UV radiation } \\
\text { (SD) [units] }\end{array}$ & $5.0(2.5)$ & $6.9(2.3)$ \\
\hline & Mean Vitamin D Intake (SD) [IU] & $222.8(144.4)$ & $215.7(150.3)$ \\
\hline & Mean 25(OH)D (SD) [ng/ml] & $25.9(8.8)$ & $19.1(7.1)$ \\
\hline
\end{tabular}

Abbreviations: PGS, polygenic score; SD, standard deviation; BMI, body mass index; UV, ultraviolet ${ }^{a}$ MANOVA global test (performed in SAS (version 9.4) revealed differences in one or more variables by cohort, therefore cohort was adjusted for in all models that included multiple cohorts

${ }^{b}$ Notably greater \% Female than other sets, because this set includes independent samples in MESA $(n=342)$ and $\mathrm{WHI}(\mathrm{n}=700)$ 
Table 3: Performance of optimal PGS in each ancestry

\begin{tabular}{|c|c|c|c|c|c|}
\hline Ancestry & p-value cut-off & \# SNPs & Cohort & PGS R ${ }^{2}$ (model $R^{2}$ ) & p-value ${ }^{a}$ \\
\hline \multirow[t]{2}{*}{ European } & \multirow[t]{2}{*}{0.00035} & \multirow[t]{2}{*}{341} & Tuning $(n=1,000)$ & $0.014(0.14)$ & $9.3 \times 10^{-5}$ \\
\hline & & & Validation $(n=8,569)$ & $0.0098(0.17)$ & $1.1 \times 10^{-23}$ \\
\hline \multirow[t]{2}{*}{ African } & \multirow[t]{2}{*}{0.01265} & \multirow[t]{2}{*}{32,269} & Tuning $(\mathrm{n}=57)$ & $0.029(0.49)$ & 0.11 \\
\hline & & & Validation $(n=1,042)$ & $0.002(0.03)$ & 0.15 \\
\hline African & 1.0 & $N A^{b}$ & Full-Independent $(n=1,099)$ & $0.003(0.04)$ & 0.05 \\
\hline
\end{tabular}

Abbreviations: SNPs, single nucleotide polymorphism; PGS, polygenic score

${ }^{a} p$-value for association between PGS and $\log [25(\mathrm{OH}) \mathrm{D}]$

${ }^{b}$ this PGS was created via mega-analysis of three cohorts; \# SNPs varies by cohort 